University of Nebraska - Lincoln

DigitalCommons@University of Nebraska - Lincoln

Publications from USDA-ARS / UNL Faculty

U.S. Department of Agriculture: Agricultural

Research Service, Lincoln, Nebraska

2013

\title{
Altered physiology, cell structure, and gene expression of Theobroma cacao seedlings subjected to Cu toxicity
}

\author{
Vânia L. Souza \\ Instituto Federal de Educação, vlsbio@yahoo.com.br \\ Alex-Alan F. de Almeida \\ Universidade Estadual de Santa Cruz, alexalan.uesc@gmail.com \\ Jadiel de S. Souza \\ jadielsantana_@hotmail.com \\ Pedro A. O. Mangabeira \\ Universidade Estadual de Santa Cruz, pmangabeira@uesc.br \\ Raildo M. de Jesus \\ Universidade Estadual de Santa Cruz, pirovanicp@gmail.com \\ See next page for additional authors
}

Follow this and additional works at: https://digitalcommons.unl.edu/usdaarsfacpub

Souza, Vânia L.; de Almeida, Alex-Alan F.; de S. Souza, Jadiel; O. Mangabeira, Pedro A.; de Jesus, Raildo M.; Pirovani, Carlos P.; Ahnert, Dário; Baligar, Virupax C.; and Loguercio, Leandro L., "Altered physiology, cell structure, and gene expression of Theobroma cacao seedlings subjected to Cu toxicity" (2013).

Publications from USDA-ARS / UNL Faculty. 1231.

https://digitalcommons.unl.edu/usdaarsfacpub/1231

This Article is brought to you for free and open access by the U.S. Department of Agriculture: Agricultural Research Service, Lincoln, Nebraska at DigitalCommons@University of Nebraska - Lincoln. It has been accepted for inclusion in Publications from USDA-ARS / UNL Faculty by an authorized administrator of DigitalCommons@University of Nebraska - Lincoln. 


\section{Authors}

Vânia L. Souza, Alex-Alan F. de Almeida, Jadiel de S. Souza, Pedro A. O. Mangabeira, Raildo M. de Jesus, Carlos P. Pirovani, Dário Ahnert, Virupax C. Baligar, and Leandro L. Loguercio 


\title{
Altered physiology, cell structure, and gene expression of Theobroma cacao seedlings subjected to $\mathrm{Cu}$ toxicity
}

\author{
Vânia L. Souza • Alex-Alan F. de Almeida • Jadiel de S. Souza • \\ Pedro A. O. Mangabeira • Raildo M. de Jesus • Carlos P. Pirovani • \\ Dário Ahnert • Virupax C. Baligar • Leandro L. Loguercio
}

Received: 30 April 2013 / Accepted: 2 July 2013

(C) Springer-Verlag Berlin Heidelberg 2013

This article is a U.S. government work, and is not subject to copyright in the United States.

\begin{abstract}
Seedlings of Theobroma cacao CCN 51 genotype were grown under greenhouse conditions and exposed to increasing concentrations of $\mathrm{Cu}(0.005,1,2,4,8,16$, and $32 \mathrm{mg}$ $\mathrm{Cu} \mathrm{L}^{-1}$ ) in nutrient solution. When doses were equal or higher than $8 \mathrm{mg} \mathrm{Cu} \mathrm{L}^{-1}$, after $24 \mathrm{~h}$ of treatment application, leaf gas exchange was highly affected and changes in chloroplasts thylakoids of leaf mesophyll cells and plasmolysis of cells from
\end{abstract}

Responsible editor: Philippe Garrigues

V. L. Souza

Departamento de Ensino, Instituto Federal de Educação, Ciência e Tecnologia da Bahia, Rod. 148, km 04, n. 1800,

Vila Esperança, 44900-000 Irecê, BA, Brazil

e-mail: vlsbio@yahoo.com.br

A.-A. F. de Almeida $(\bowtie) \cdot$ J. de S. Souza • P. A. O. Mangabeira • C. P. Pirovani $\cdot$ D. Ahnert $\cdot$ L. L. Loguercio

Departamento de Ciências Biológicas, Universidade Estadual de Santa Cruz, Rod. BR 415, km 16, 45662-900 Ilhéus, BA, Brazil e-mail: alexalan.uesc@gmail.com

J. de S. Souza

e-mail: jadielsantana_@hotmail.com

P. A. O. Mangabeira

e-mail: pmangabeira@uesc.br

C. P. Pirovani

e-mail: pirovanicp@gmail.com

D. Ahnert

e-mail: darioa@uesc.br

L. L. Loguercio

e-mail: leandro@uesc.br

R. M. de Jesus

Departamento de Ciências Exatas e Tecnológicas,

Universidade Estadual de Santa Cruz,

Rod. BR 415, km 16, 45662-900 Ilhéus, BA, Brazil

e-mail: raildomota@gmail.com

V. C. Baligar

USDA-ARS - Sustainable Perennial Crops Laboratory, 10300

Baltimore Avenue, Beltsville, MD, USA

e-mail: v.c.baligar@ars.usda.gov the root cortical region were observed. In addition, cell membranes of roots and leaves were damaged. In leaves, $96 \mathrm{~h}$ after treatments started, increases in the percentage of electrolyte leakage through membranes were observed with increases of $\mathrm{Cu}$ in the nutrient solution. Moreover, there was an increase in the concentration of thiobarbituric acid-reactive substances in roots due to lipid peroxidation of membranes. Chemical analysis showed that increases in $\mathrm{Cu}$ concentrations in vegetative organs of $T$. cacao increased with the increase of the metal in the nutrient solution, but there was a greater accumulation of $\mathrm{Cu}$ in roots than in shoots. The excess of $\mathrm{Cu}$ interfered in the levels of $\mathrm{Mn}, \mathrm{Zn}, \mathrm{Fe}, \mathrm{Mg}, \mathrm{K}$, and $\mathrm{Ca}$ in different organs of $T$. cacao. Analysis of gene expression via RTq-PCR showed increased levels of $M T 2 b, S O D C y t$, and PER-1 expression in roots and of MT2b, PSBA, PSBO, SODCyt, and SODChI in leaves. Hence, it was concluded that $\mathrm{Cu}$ in nutrient solution at doses equal or above $8 \mathrm{mg} \mathrm{L}^{-1}$ significantly affected leaf gas exchange, cell ultrastructure, and transport of mineral nutrients in seedlings of this T. cacao genotype.

Keywords Cacao $\cdot$ Heavy metal $\cdot$ Lipid peroxidation $\cdot$ Photosynthesis · Ultrastructure · Gene expression

\section{Introduction}

Copper is a heavy metal and micronutrient essential for plant metabolism, occurring under physiological conditions as $\mathrm{Cu}^{2+}$ and $\mathrm{Cu}^{+} . \mathrm{Cu}$ ions are vital components of a variety of enzymes and other proteins, including transcription factors. Thus, for the plant to grow and develop in a healthy manner, $\mathrm{Cu}$ has to be taken from the soil, transported across membranes, distributed and compartmentalized in different tissues, with its amounts precisely regulated within the cells (Yruela 2005). Excess of $\mathrm{Cu}$ inhibits the activity of several enzymes and interferes with various aspects of plant biochemistry, including photosynthesis, metabolism of fatty 
acids and proteins, respiration, and integrity of membranes (Almeida et al. 2007). The most important of these effects is related to photosynthesis, in which $\mathrm{Cu}$ excess leads to changes in the ultrastructure of chloroplasts, causing reduction of electron transport in photosystems I (PS I) and II (PS II); it also interferes with the activity of Calvin cycle enzymes, such as the Rubisco (Panou-Filotheou et al. 2001; Pätsikkä et al. 2002; Shaul 2002). Therefore, decreases in net photosynthetic rate $\left(P_{\mathrm{N}}\right)$, stomatal conductance $(\mathrm{gs})$, and transpiration $(E)$ are common in plants exposed to excess of $\mathrm{Cu}$ (Moustakas et al. 1997; Vassilev et al. 2002; Shi-Sheng 2007; Cambrollé et al. 2011). In addition, $\mathrm{Cu}$ excess promotes the production of free radicals that cause damage to proteins and lipids of cellular membranes, thereby altering their permeability and selectivity for intake/exit of nutrients to/from the cell, which can cause electrolytes leakage (ShiSheng 2007). The malondialdehyde (MDA), originated from a reaction between a free radical and a polyunsaturated fatty acid, is commonly used as an indicator of lipid peroxidation in membranes of plant cells under stress conditions by $\mathrm{Cu}$ excess (Pätsikkä et al. 2002; Bouazizi et al. 2010; Janas et al. 2010). Despite that $\mathrm{Cu}$ accumulates mainly in roots, it interferes with the chemical composition of different plant organs, which levels of nutritional imbalance is speciesdependent (Shi-Sheng 2007; Bouazizi et al. 2010; Cambrollé et al. 2011). For instance, in Glaucium flavum exposed to excess of $\mathrm{Cu}, \mathrm{P}$ concentration increased in roots and leaves, whereas $\mathrm{Ca}$ and $\mathrm{Mg}$ levels decreased in leaves (Cambrollé et al. 2011). Bouazizi et al. (2010) observed a decrease in the levels of $\mathrm{Fe}, \mathrm{Zn}$ and $\mathrm{K}$ in the leaves of Phaseolus vulgaris; the same was observed for $\mathrm{Fe}, \mathrm{K}$, and $\mathrm{Mg}$ contents in seedlings of Amaranthus tricolor (Shi-Sheng 2007).

Plants have several potential strategies and mechanisms at the cellular level that may be involved in detoxification and tolerance to stresses caused by heavy metals. Tolerant plants show an increase in several homeostatic mechanisms, which contribute to prevent the metal translocation (Hall 2002), or to keep it in a stable manner. With regards to $\mathrm{Cu}$, a form of protection employed by some plant species consists in increasing metallothionein levels, which act mainly as chelator of the metal in excess (Cobbett and Goldsbrough 2002). Metallothioneins are low molecular weight proteins, rich in cysteine residues that bind to copper and protect the cells against the toxicity of this element (van Hoof et al. 2001). Antioxidant enzymes, such as superoxide dismutases (SODs) and class III peroxidases, represent another mechanism of tolerance to $\mathrm{Cu}$ stress. These enzymes act by limiting the formation and by removing the reactive oxygen species (ROS) (Alscher et al. 2002). The SOD enzymes are classified into three groups: Fe SOD, Mn SOD, and $\mathrm{Cu}-\mathrm{Zn}$ SOD, which are located in different cell compartments (Alscher et al. 2002). The $\mathrm{Cu}-\mathrm{Zn}$ SODs enzymes are divided into two classes of isoforms, one located in the cytoplasm and the other in the chloroplasts (Kurepa et al. 1997). The class III peroxidases are located in vacuoles and cell walls, belong to a multigene family involved in several physiological processes, and act in a wide variety of substrates, showing moderate specificity for phenols (Almagro et al. 2009).

Seeds of Theobroma cacao (Malvaceae) are commercially explored for chocolate production, as well as for other derivatives and by-products such as cosmetics, fine drinks, jams, icecreams and juices (Almeida and Valle 2010). The southeastern region of Bahia, Brazil, has been the main cacao-growing region in the world for over a hundred years. However, with the outbreak of witches' broom disease of cacao at the end of the 1980s, caused by the basidiomycete Moniliophthora perniciosa, an economic, social, and environmental disaster struck this region, as a consequence of a drastic reduction in cacao beans production (Pereira et al. 1989). In the past 15 years, a major control method of this and other diseases (such as the black-pod rot caused by Phytophthora spp.), has been the development and use of resistant and tolerant cacao genotypes, coupled with other cultural and chemical control measures under an integrated management approach. A couple of these measures have been the use of phosphate fertilizers and cupric fungicides (Fonseca 1990). Therefore, in this cacao-producing region, the accumulation of $\mathrm{Cu}$ in soils, plants and, consequently, in cacao beans is a matter of concern, because the control of black-pod and witches' broom with cupric fungicides has been a common practice throughout all these years, as part of the technological package recommended for this crop (Veloso and Santana 2000). It was found that the content of $\mathrm{Cu}$ in these cacao-crop soils (at the Bahian municipalities of Camacan, Ilhéus, Itabuna, Pau Brasil, and Uruçuca) has increased proportionally to the time of its applications. In places where this practice has been systematically employed from 5 to 20 years, the available and total soil $\mathrm{Cu}$ contents were found to be above the appropriate levels (Veloso and Santana 2000).

Taking this context into consideration, the main objectives of this study were to evaluate the tolerable physiological limits of exposure to $\mathrm{Cu}$ by $T$. cacao seedlings, when grown in nutrient solution with different concentrations of this element, as well as to assess translocation of $\mathrm{Cu}$ to the shoots and the overall changes on plants exposed to high levels of this metal. These objectives were achieved by verifying the variation caused by $\mathrm{Cu}$ in leaf gas exchange, ultrastructure of cellular organelles, peroxidation of cell membranes and mineral nutrients composition, both in roots and shoots.

\section{Material and methods}

Plant material and growth conditions

The experiment was conducted under greenhouse conditions at the Universidade Estadual de Santa Cruz (UESC), Ilhéus, Bahia, Brazil. Seeds of the T. cacao genotype CCN 51 were 
grown in black plastic tubes containing Pinus bark and turf+triturated coconut fiber (1:1) as substrate. Approximately 30 days after emergence, plants were transplanted into $35-\mathrm{L}$ plastic trays (eight plants per tray), containing nutrient solution at $1 / 2$ ionic strength, prepared according to Hoagland and Arnon (1950). For acclimation, the plants remained in these conditions for 2 months. Once this period was completed, the treatments with increasing concentrations of $\mathrm{Cu}(0.005,1,2,4,8,16$, and $32 \mathrm{mg} \mathrm{L}^{-1}$ ) in the form of $\mathrm{CuSO}_{4} \cdot 7 \mathrm{H}_{2} \mathrm{O}$ were applied. The concentration of $0.005 \mathrm{mg} \mathrm{Cu} \mathrm{L}^{-1}$ was considered as the control concentration, because $\mathrm{Cu}$ is an essential micronutrient for growth and development of plants. During the experimental period, the solutions were monitored daily for $\mathrm{pH}$, which was adjusted to 5.5 using $\mathrm{NaOH}$ and/or $\mathrm{HCl}$. The nutrient solution was kept under constant aeration and its level maintained by addition of deionized water. Renewal of the nutrient solution was made weekly.

\section{Leaf gas exchange}

During the experimental period, the net photosynthetic rate per unit of leaf area $\left(P_{\mathrm{N}}\right)$, stomatal conductance to water vapor (gs) and leaf transpiration $(E)$ were measured at 24 , 48, 72, and $96 \mathrm{~h}$ after $a$ pplication of treatments (AAT). These variables were assessed, between 0800 and $0900 \mathrm{~h}$, on a mature and completely expanded leaf from the end the orthotropic apex axis of four plants per treatment using a portable photosynthesis system LI-6400 (Li-Cor, Nebraska, USA) equipped with an artificial light source 6400-02B RedBlue.

The values of $P_{\mathrm{N}}$, gs, and $E$ were used to calculate the intrinsic $\left(P_{\mathrm{N}} / \mathrm{gs}\right)$ and the instantaneous $\left(\mathrm{WUE}=P_{\mathrm{N}} / E\right)$ water use efficiencies. For the leaf gas exchange measurements, the artificial light source of the system was adjusted to provide a photosynthetic photon flux density of $800 \mu \mathrm{mol} \mathrm{m} \mathrm{m}^{-2} \mathrm{~s}^{-1}$. The mean values of atmospheric $\mathrm{CO}_{2}$ concentration, air temperature and air vapor pressure deficit during the leaf gas exchange measurements were $421.47 \pm 11.94 \mu \mathrm{mol} \mathrm{mol}{ }^{-1}$, $26.7 \pm 0.07^{\circ} \mathrm{C}$, and $1.56 \pm 0.04 \mathrm{kPa}$, respectively (mean $\pm \mathrm{SD}$, $n=35$, corresponding to 7 treatments $\times 5$ replications).

\section{Ultrastructural assessment}

Ultrastructural analyses were performed using a transmission electron microscopy (TEM) on the root tip and middle portion of the second mature leaf from the apex of the orthotropic axis harvested at $96 \mathrm{~h}$ AAT. The plant material was fixed in $3 \%$ glutaraldehyde in $0.1 \mathrm{M}$ sodium cacodylate buffer ( $\mathrm{pH}$ 7.2). Samples were submitted to four washes (10 min each) in $0.1 \mathrm{M}$ sodium cacodylate buffer, $\mathrm{pH}$ 7.2, and post-fixed in $1 \%$ osmium tetroxide, prepared in the same buffer for $2 \mathrm{~h}$ at $4{ }^{\circ} \mathrm{C}$, and followed by dehydration in an ethanol gradient $(30,50,70,80$, and $90 \%$ ethanol), and by two washes in $100 \%$ ethanol. Then, the samples were embedded in a mixture of $100 \%$ ethanol and LR White resin (Sigma) in the proportions 3:1 (2 h), 1:1 (2 h), 1:3 (overnight), followed by two changes of pure LR White resin of $4 \mathrm{~h}$ each, always under slow agitation. The samples were placed in gelatin capsules and covered with pure LR White resin. Polymerization of the resin was completed in $24 \mathrm{~h}$ at $60^{\circ} \mathrm{C}$. Ultra thin sections $(60-70 \mathrm{~nm})$ were cut on a diamond knife using a ultramicrotome (model EM FC6 LEICA Microsystems), and collected from the knife's water bath on 300-mesh $\mathrm{Cu}$ grids. The sections were stained for $15 \mathrm{~min}$ with aqueous solution of $5 \%$ uranyl acetate, followed by $20 \mathrm{~min}$ with $0.4 \%$ lead citrate (Reynolds 1963 ). Analyses were done using Morgani ${ }^{\mathrm{TM}}$ 268D TEM (FEI Company), with acceleration voltage of $80 \mathrm{kV}$, equipped with a CCD camera and controlled by software running under Windows OS. At least four grids with three to five sections for each treatment were observed and photographed. The images that best represented the changes in the ultrastructure of T. cacao leaf mesophyll and root cells, after application of different concentrations of $\mathrm{Cu}$, were selected.

\section{Electrolyte leakage}

To assess the cell membrane stability, the electrolyte leakage technique was used (Bajji et al. 2001). Leaf discs were cut out of plants submitted to different $[\mathrm{Cu}]$ in nutrient solution at $96 \mathrm{~h} \mathrm{AAT}$, and thoroughly washed in deionized water. Afterwards, the leaf discs were placed in vials containing $10 \mathrm{~mL}$ of deionized water at $25{ }^{\circ} \mathrm{C}$ for $6 \mathrm{~h}$ under constant agitation. The electrical conductivity was measured using a conductivity meter and expressed as percentage of total conductivity, which was obtained after placing the vials with the leaf discs at $90^{\circ} \mathrm{C}$ for $2 \mathrm{~h}$.

\section{Lipid peroxidation}

Oxidative damage to lipids in cell membranes of roots and leaves were estimated as thiobarbituric acid-reactive substances (TBARS), mainly MDA, according to Cakmak and Horst (1991) with some modifications. For each of the different $\mathrm{Cu}$ treatments, $20 \mathrm{mg}$ of lyophilized roots or leaves were homogenized in a mortar with $2 \mathrm{~mL}$ of $0.1 \%(w / v)$ trichloroacetic acid (TCA). Following centrifugation at $10,000 \times g$ for $5 \mathrm{~min}$, an aliquot of $500 \mu \mathrm{L}$ from the supernatant was added to $1.5 \mathrm{~mL}$ of thiobarbituric acid solution $\left(0.5 \%\right.$ in $20 \%$ TCA). Samples were incubated at $90{ }^{\circ} \mathrm{C}$ for $20 \mathrm{~min}$. After heating, the reaction was stopped under ice bath. Centrifugation at $10,000 \times g$ for 4 min was performed, and then the absorbance of supernatant was read at $532 \mathrm{~nm}$ and corrected for non-specific turbidity by subtracting the absorbance at $600 \mathrm{~nm}$. The concentration of TBARS was calculated from its extinction coefficient of $155 \mathrm{mM}^{-1} \mathrm{~cm}^{-1}$. 


\section{Mineral nutrients}

At the end of the experiment ( $96 \mathrm{~h} \mathrm{AAT),} \mathrm{three} \mathrm{seedlings} \mathrm{per}$ tray were collected from the different treatments and separated in roots, stems, and leaves. Soon after, washes were carried out once in tap water, once in $3 \% \mathrm{HCl}$, and twice in deionized water; the different vegetative organs were placed in an oven at $75^{\circ} \mathrm{C}$ to obtain dry biomass. Dry plant materials were grinded using a Wiley mill to pass a 20-mesh screen, and analyzed chemically (Anunciação et al. 2011). Concentrations of $\mathrm{Cu}, \mathrm{Fe}, \mathrm{Mn}, \mathrm{Zn}, \mathrm{Mg}, \mathrm{K}$, and $\mathrm{Ca}$ were analyzed in root, stem and leaf dry matter, using inductively coupled plasma-optical emission spectrometer, in a "Varian 710-ES" model.

\section{Quantitative real-time PCR analysis}

Samples of roots and second mature leaf from the apex of the orthotropic axis were harvested at 12 and $96 \mathrm{~h}$ AAT, frozen in liquid nitrogen and stored at $-80{ }^{\circ} \mathrm{C}$. Prior to RNA extraction, the tissues were lyophilized. RNA was extracted from roots and leaves at four different treatments $(0.005,2,4$, and $8 \mathrm{mg} \mathrm{Cu} \mathrm{L}^{-1}$ ) with RNAqueous kit (Ambion ${ }^{\circledR}$ ). The RNA purity and integrity was checked by electrophoresis in $1 \%$ agarose gels. The RNA samples were used for cDNA synthesis using Revertaid H-Minus Reverse Transcriptase (Fermentas) and oligo $\mathrm{d}(\mathrm{T})_{18}$ primers, according to manufacturer instructions. The reactions were incubated at $65^{\circ} \mathrm{C}$ for $5 \mathrm{~min}, 37^{\circ} \mathrm{C}$ for $5 \mathrm{~min}, 42^{\circ} \mathrm{C}$ for $60 \mathrm{~min}$ and $70{ }^{\circ} \mathrm{C}$ for $10 \mathrm{~min}$. The qPCR was performed in a "Real Time PCR" (Applied Biosystems, 7500 model) using non-specific sequence fluorophore SYBR Green I (Fermentas). The abundance of transcripts was analyzed using specific primers (Table 1). To test the quality of these primers, the specificity and identity of the reverse transcription products, the qPCR products were monitored after each PCR, using a melt-curve analysis distinguishing gene-specific from non-specific products. The reaction mix consisted of cDNA template (500 ng), $0.5 \mu \mathrm{M}$ of each primer, and $10 \mu \mathrm{L}$ fluorophore SYBR Green I in a final reaction volume of $20 \mu \mathrm{L}$. The temperature of PCR products was raised from 55 to $99^{\circ} \mathrm{C}$ at a rate of $1{ }^{\circ} \mathrm{C} / 5 \mathrm{~s}$, and the resulting data were analyzed using the LightCycler software. Only a single band with a characteristic melting point was observed for each sample, indicating that the qPCR had produced a specific product for each primer-pair used. To confirm that the qPCR had produced only genes of interest, the PCR products were separated and visualized in agarose gel at $1 \%$. Threshold cycle $\left(C_{\mathrm{T}}\right)$ values were determined using the LightCycler software. Numbers on the relative expression of genes were calculated as a percentage of the control treatments $\left(0.005 \mathrm{mg} \mathrm{Cu} \mathrm{L}^{-1}\right)$, using the $2^{-\Delta \Delta \mathrm{Ct}}$ method (Livak and Schmittgen 2001) and $\beta$-Tubulin as endogenous control in order to detect changes in transcript number (Table 1). All reactions were prepared in triplicate and performed twice. For each treatment at different times (12 and $96 \mathrm{~h} \mathrm{AAT),} \mathrm{three} \mathrm{biological} \mathrm{replicas} \mathrm{were}$ used for each primer evaluation.

\section{Statistics}

The experiment was performed on a completely randomized arrangement, with seven levels of $\mathrm{Cu}$, containing five replicates of eight seedlings each. The results were analyzed based on linear and non-linear mathematical models, with variation of $\mathrm{Cu}$ concentration in a nutrient solution as independent variable and leaf gas exchange, percentage of electrolyte leakage, lipid peroxidation, and mineral nutrient as dependent variables. Regression analyses and analyses of variance to define the best fitting model were done utilizing the general linear model procedure of the "Statistical Analysis System" (SAS Institute 1997), using methodology outlined by Steel and Torrie (1980). The coefficients of the equations were tested using $t$ test $(p<0.05)$. The statistical analysis of expression levels was performed using ANOVA. Mean comparisons were performed by Tukey's test with statistical significance at $p<0.05$.

\section{Results}

Leaf gas exchange

Leaf gas exchange of T. cacao seedlings was highly affected after $24 \mathrm{~h}$ exposure to concentrations of 8,16 and $32 \mathrm{mg} \mathrm{Cu}$ $\mathrm{L}^{-1}$ in nutrient solution. Decreases of up to 72,75 , and $73 \%$ for $P_{\mathrm{N}}$, gs, and $E$, respectively, were observed (Fig. 1a-c). At $96 \mathrm{~h} \mathrm{AAT}$ for the $32 \mathrm{mg} \mathrm{Cu} \mathrm{L}^{-1}$ dose, these decreases reached 100,99 , and $98 \%$ for $P_{\mathrm{N}}$, gs, and $E$, respectively. On the other hand, for the $4 \mathrm{mg} \mathrm{Cu} \mathrm{L}^{-1}$ treatment, the decrease in $P_{\mathrm{N}}$ was of $44 \%$ at $96 \mathrm{~h} \mathrm{AAT}$. The values of gs and $E$ for the same concentration at $24 \mathrm{~h}$ AAT showed lower decreases of 39 and $38 \%$, respectively, without significant differences $(p<0.05)$ for the corresponding values at $96 \mathrm{~h}$ AAT.

The intrinsic and instantaneous water use efficiencies $\left(P_{\mathrm{N}} / \mathrm{gs}\right.$ and WUE) did not show a significant variation at 24 and $48 \mathrm{~h}$ AAT. However, a decline was found at $72 \mathrm{~h}$ AAT for both $P_{\mathrm{N}} / \mathrm{gs}$ and $W U E$ (Fig. 1d, e). These results are striking in demonstrating that seedlings of $T$. cacao were physiologically affected by as short as 24-h exposure to increasing concentrations of $\mathrm{Cu}$ in nutrient solution; values up to $2 \mathrm{mg} \mathrm{Cu} \mathrm{L}^{-1}$ were beneficial, and above it were detrimental. The results showed that the relationship between $P_{\mathrm{N}}$ and gs (Fig. 2) was linear up to a gs value of $0.03 \mathrm{~mol} \mathrm{H}_{2} \mathrm{O} \mathrm{m}^{-2} \mathrm{~s}^{-1}$ for the $4 \mathrm{mg} \mathrm{Cu} \mathrm{L}^{-1}$ concentration. The lowest values of this ratio were obtained for concentrations equal and above $8 \mathrm{mg} \mathrm{Cu} \mathrm{L}^{-1}$, whereas the highest values of $P_{\mathrm{N}}$ and gs were found for the concentrations of 1 and $2 \mathrm{mg} \mathrm{Cu} \mathrm{L}^{-1}$. 
Table 1 Pairs of gene-specific primers used in the qRT-PCR analysis

\begin{tabular}{|c|c|c|c|}
\hline Gene & Acesso & Function & Primer \\
\hline$M T 2 b$ & CL9Contig $1^{\mathrm{b}}$ & Biosynthesis of metallothionein & $\begin{array}{l}\text { F-5'-GCAACCCTTGCACTTGTAAATG-3' } \\
\text { R-5'-CAAGCCATGGCAACTTTATTCTAA-3' }\end{array}$ \\
\hline PER-1 & CK144296. $1^{\mathrm{a}}$ & Biosynthesis of peroxidase class III & $\begin{array}{l}\mathrm{F}-5^{\prime}=\text { CAGGTGTCGTGGGATCAAGA-3' } \\
\mathrm{R}-5^{\prime} \text {-TGGAAAAACTACGCCAAATATGC-3' }\end{array}$ \\
\hline$C u-Z n S O D_{C y t}$ & CL94Contig $1^{\mathrm{b}}$ & Biosynthesis of cytosolic $\mathrm{Cu}-\mathrm{Zn}$ SOD & $\begin{array}{l}\mathrm{F}-5^{\prime} \text {-GATGATGGCTGTGTGAGTTTCTCT-3' } \\
\mathrm{R}-5^{\prime} \text {-CAACAACAGCTCTTCCAATAATTGA-3' }\end{array}$ \\
\hline$C u-Z n S O D_{C h l}$ & CL872Contig $1^{\mathrm{b}}$ & Biosynthesis of chloroplastic $\mathrm{Cu}-\mathrm{Zn}$ SOD & $\begin{array}{l}\text { F-5'-AATGGATGCATGTCAACAGGAGC-3' } \\
\text { R-5'-ATGTTTCCCAGGTCACCCGC-3' }\end{array}$ \\
\hline$P S B O$ & CL326Contig $1^{\mathrm{b}}$ & Biosynthesis of PsbO protein & $\begin{array}{l}\text { F-5'-GCAAACGCTGAAGGAGTT-3' } \\
\text { R-5'-GGCTTGAAGGCAAATGAGTC-3' }\end{array}$ \\
\hline$P S B A$ & NC_014676.2 $2^{\mathrm{c}}$ & Biosynthesis of the PsbA protein or D1 protein & $\begin{array}{l}\text { F-5'-GGTTTGCACTTTTACCCGA-3' } \\
\text { R-5'-CTCATAAGGACCGCCATT-3' }\end{array}$ \\
\hline$\beta$-Tubulin & GU570572.1 $1^{\mathrm{c}}$ & Endogen & $\begin{array}{l}\mathrm{F}-5^{\prime} \text {-TGCAACCATGAGTGGTGTCA-3' } \\
\mathrm{R}-5^{\prime} \text {-CAGACGAGGGAAAGGAATGA-3' }\end{array}$ \\
\hline
\end{tabular}

${ }^{\mathrm{a}} \mathrm{http}: / /$ cocoagendb.cirad.fr/

${ }^{\mathrm{b}}$ http://esttik.cirad.fr/index.html

${ }^{\mathrm{c}} \mathrm{http}: / /$ www.ncbi.nlm.nih.gov/

Ultrastructural assessment

The effects of increasing concentrations of $\mathrm{Cu}$ on cellular ultrastructure of developing $T$. cacao seedlings were assessed by TEM. Changes in root and leaf mesophyll cortex cells were observed (Figs. 3 and 4), with occurrence of plasmolysis in root cortex cells mainly above $8 \mathrm{mg} \mathrm{Cu} \mathrm{L}^{-1}$ (Fig. 3a-f), shown by contraction of the plasma membrane and tonoplast shrinkage. $\mathrm{Cu}$ treatment apparently led to the rupture of plasma membranes in some cells of the cortical root tissue (Fig. 3g-1).

An evidence that $\mathrm{Cu}$ concentrations in nutrient solution between 4 and $8 \mathrm{mg} \mathrm{Cu} \mathrm{L}^{-1}$ seems to establish the limit from beneficial to detrimental effects in $T$. cacao seedlings was also observed from ultrastructural analysis of chloroplasts (Fig. 4). Organelles of leaf mesophyll cells of seedlings submitted to 0.005 (control), 2, and $4 \mathrm{mg} \mathrm{Cu} \mathrm{L}{ }^{-1}$ looked normal through TEM. Chloroplasts showed structured and organized thylakoid membranes, normal presence of starch grains and plastoglobuli, and intact double membranes of their envelope (Fig. 4a-c). Contrariwise, from concentrations of $8 \mathrm{mg} \mathrm{Cu} \mathrm{L}^{-1}$ and above, the chloroplast envelopes and thylakoids became disorganized (Fig. $4 \mathrm{~d}-\mathrm{f}$ ), and absence of starch grains in the stroma, swollen thylakoids, and increased interthylakoidal space were verified. Furthermore, the rupture of the outer and inner doublemembrane surrounding the chloroplast was found in some samples (Fig. 4d-e).

Electrolyte leakage and lipid peroxidation

The damage to membranes caused by $\mathrm{Cu}$ excess can be quantified indirectly by assessing electrolytes leakage. As shown in Fig. 5a, there was an increase in the percentage of electrolyte leakage through leaf mesophyll cells membranes of $T$. cacao seedlings with increasing $\mathrm{Cu}$ in the nutrient solution. In order to check if membrane damage also occurred as a result of lipids peroxidation, the concentration of TBARS was determined. Results indicated that there was no significant difference $(p<0.05)$ between treatments in relation to lipid peroxidation of leaf mesophyll cell membranes with increasing $\mathrm{Cu}$ in nutrient solution; however, in roots, from the $8 \mathrm{mg} \mathrm{Cu} \mathrm{L}^{-1}$ treatment and above, a significant increase of TBARS concentration was observed (Fig. 5b).

\section{Mineral nutrients}

The effects of exposure to increasing $\mathrm{Cu}$ concentrations were also studied in terms of variations in mineral composition of vegetative organs of $T$. cacao seedlings. Chemical analysis showed that $\mathrm{Cu}$ concentrations in roots and shoots of T. cacao was proportional to its increased concentration in the nutrient solution, but the accumulation of $\mathrm{Cu}$ in roots was largely higher than in shoots (Fig. 6). For the treatment with the highest concentration of the metal at $96 \mathrm{~h} \mathrm{AAT}$, the concentration of $\mathrm{Cu}$ in the roots was $1,032 \mathrm{mg} \mathrm{Cu} \mathrm{kg}^{-1} \mathrm{DW}$, whereas in stem and leaves, the accumulation was only 17 and $6 \mathrm{mg} \mathrm{Cu}$ $\mathrm{kg}^{-1} \mathrm{DW}$, respectively (Fig. 6). These corresponded to an accumulation of $\mathrm{Cu}$ in stems and leaves that was approximately $60 \times$ and near $175 \times$ smaller than in roots.

The increase in $\mathrm{Cu}$ amounts in the nutrient solution interfered with the concentrations of $\mathrm{Mn}, \mathrm{Zn}, \mathrm{Fe}, \mathrm{Mg}, \mathrm{K}$, and $\mathrm{Ca}$, both in roots and shoots. There was a sharp decline in $\mathrm{Mn}$ and $\mathrm{Zn}$ concentrations in roots and stems that level off with 


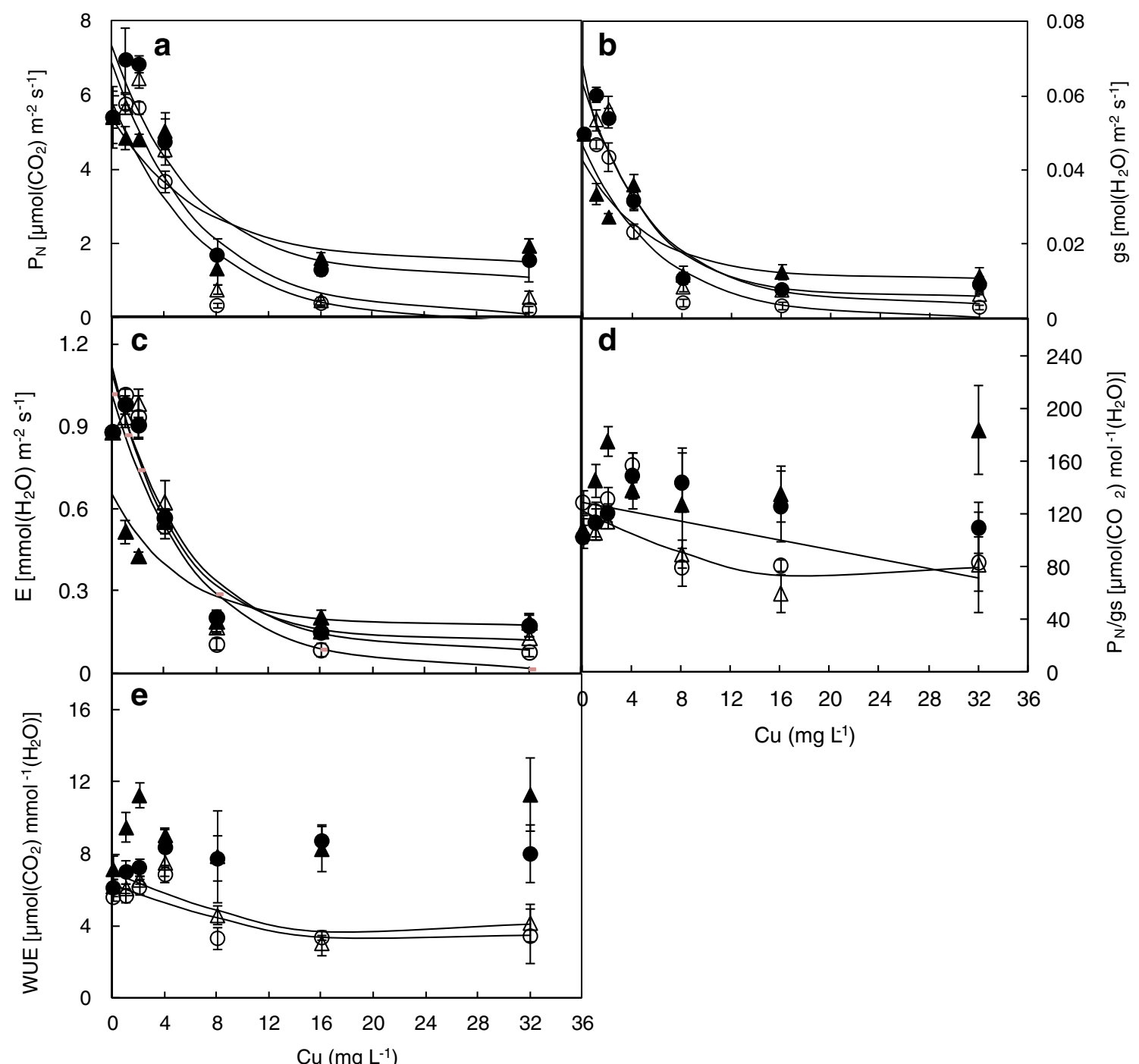

Fig. 1 Changes in a net photosynthetic rate $\left(P_{\mathrm{N}}\right)$, b stomatal conductance to water vapor (gs), $\mathbf{c}$ transpiration $(E), \mathbf{d}$ ratio of the intrinsic water use efficiency $\left(P_{\mathrm{N}} / \mathrm{gs}\right)$, and $\mathbf{e}$ instantaneous water use efficiency $(W U E)$ in leaves of young plants of T. cacao exposed to different concentrations of $\mathrm{Cu}$ in nutrient solution during 24 (filled upright triangle), 48 (filled circle), 72 (open upright triangle), and 96 h (open circle), $n=4, \pm \mathrm{SE}$. The regression curve equations were: $\widehat{y}_{24}=1.45+3.96 \exp$ $(-0.14 x)\left(r^{2}=0.66\right), \widehat{y}_{48}=1.03+6.3 \exp (-0.15 x)\left(r^{2}=0.75\right)$, $y_{72}=0.03+6.84 \operatorname{ex}(-0.14 x)\left(r^{2}=0.87\right), \quad \widehat{y}_{96}=0.22+6.07 \exp$ $(-0.14 x)\left(r^{2}=0.76\right)$ for $P_{\mathrm{N}} ; \hat{y}_{24}=0.01+0.031 \exp (-0.18 x)$

$\left(r^{2}=0.71\right), \widehat{y}_{48}=0.006+0.062 \exp (-0.20 x)\left(r^{2}=0.88\right), \widehat{y}_{72}=$ $0.003+0.059 \exp (-0.17 x)\left(r^{2}=0.86\right), \quad \widehat{y}_{96}=0.006+0.062 \exp$ $(-0.20 x) \quad\left(r^{2}=0.74\right)$ for gs; $\widehat{y}_{24}=0.17+0.47 \exp (-0.18 x)\left(r^{2}=\right.$ $0.71), \widehat{y}_{48}=0.11+1.004 \exp (-0.20 x)\left(r^{2}=0.89\right), \widehat{y}_{72}=0.07+$ $1.01 \exp (-0.17 x)\left(r^{2}=0.87\right), \quad \widehat{y}_{96}=0.01+1.009 \exp (-0.16 x)$ $\left(r^{2}=0.77\right)$ for $E ; \widehat{y}_{24}=142.54, \widehat{y}_{48}=126.38, \widehat{y}_{72}=122.44-4.75 x$ $+0.11 x^{2}\left(r^{2}=p t 0.57\right), \widehat{y}_{96}=128.97-1.8 x\left(r^{2}=0.46\right)$ for $P_{\mathrm{N}} / \mathrm{gs}$; $\widehat{y}_{24}=9.30, \widehat{y}_{48}=6.73, \widehat{y}_{72}=6.97-0.32 x+0.0073 x^{2}\left(r^{2}=0.70\right)$, $\widehat{y}_{96}=6.30-0.28 x+0.006 x^{2}\left(r^{2}=0.66\right)$ for WUE. The measurements were made at $800 \mu \mathrm{mol} \mathrm{m}{ }^{-2} \mathrm{~s}^{-1}$ PPFD

the increase of $\mathrm{Cu}$ in the nutrient solution (Fig. 7). The lowest concentrations of $\mathrm{Mn}$ and $\mathrm{Zn}$ in the roots were 49 and $38 \mathrm{mg}$ $\mathrm{kg}^{-1} \mathrm{DW}$, representing a decline of 81 and $55 \%$, respectively, when compared to control plants. In the stems, the lowest concentrations of these micronutrients were higher than in roots, with values of $115 \mathrm{mg} \mathrm{Mn} \mathrm{kg}{ }^{-1} \mathrm{DW}$ and $79 \mathrm{mg} \mathrm{Zn}$ $\mathrm{kg}^{-1}$ DW representing a decrease of 52 and $40 \%$, respectively, when compared to controls. On the other hand, Fe increased in roots and leaves with increasing $\mathrm{Cu}$ amounts in the nutrient solution (Fig. 7), with 95 and $61 \%$ increases, respectively. The maximum values observed for roots and leaves were 477 and $79 \mathrm{mg} \mathrm{Fe} \mathrm{kg}^{-1} \mathrm{DW}$, while the control plants had values of 244 and $49 \mathrm{mg} \mathrm{Fe} \mathrm{kg}^{-1} \mathrm{DW}$, respectively.

The reduction observed in Mg both for stems and leaves was also proportional to the increased exposure to $\mathrm{Cu}$. The maximum and minimum levels of $\mathrm{Mg}$ in the stems were 9.42 and $7.16 \mathrm{~g}$ $\mathrm{Mg} \mathrm{kg}^{-1} \mathrm{DW}$, respectively, whereas in leaves they were 5.24 and $3.83 \mathrm{~g} \mathrm{Mg} \mathrm{kg}^{-1} \mathrm{DW}$, respectively, representing a decrease of $24 \%$ in stems and $26 \%$ in leaves (Fig. 8). There was a decrease in $\mathrm{K}$ concentrations in roots and stems as $\mathrm{Cu}$ increased in the nutrient solution. The minimum values of $\mathrm{K}$ found in roots and stems were 15 and $16 \mathrm{~g} \mathrm{~K} \mathrm{~kg}^{-1} \mathrm{DW}$, respectively, representing 


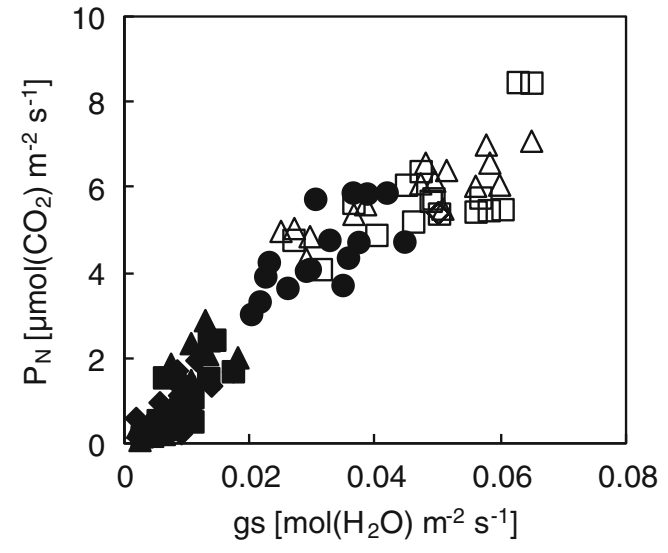

Fig. 2 Relationship between net photosynthetic rate per unit leaf area $\left(P_{\mathrm{N}}\right)$ and stomatal conductance to water vapor $(\mathrm{gs})$ in young plants of $T$. cacao submitted to the concentrations 0.005 (open circle), 1 (open square), 2 (open upright triangle), 4 (filled circle), 8 (filled square), 16 (filled diamond), and 32 (filled upright triangle) $\mathrm{mg} \mathrm{Cu} \mathrm{L}^{-1}$ in nutrient solution during $24,48,72$, and $96 \mathrm{~h}(n=4)$. The measurements were made at $800 \mu \mathrm{mol} \mathrm{m} \mathrm{m}^{-1}$ PPFD a decrease of 33 and $17 \%$ compared to control (Fig. 8). The $\mathrm{Ca}$ concentrations increased up to $22 \%$ in root tissues at the highest $\mathrm{Cu}$ concentration in the nutrient solution (Fig. 8). Conversely, in stems, there was a decrease of $24 \%$ in Ca concentration in relation to control plants.

\section{Quantitative real-time PCR analysis}

From the morpho-physiological changes in roots and leaves of seedlings when exposed to increasing concentrations of $\mathrm{Cu}$, it was possible to select the doses that best represented the behavior of T. cacao to toxic $\mathrm{Cu}$ levels to allow assessment of gene expression at the transcriptional level. A significant increase $(p<0.05)$ in the transcription levels of the MT2b, SODCyt and $P E R-1$ genes in roots, and $P S B A$ and $P S B O$ genes in leaves was observed at $12 \mathrm{~h} \mathrm{AAT}$ for the concentration $8 \mathrm{mg} \mathrm{Cu} \mathrm{L}^{-1}$, when compared to controls (Fig. 9a-e). However, at $96 \mathrm{~h}$ ATT in the roots, only the expression of the PER-1 gene remained two times greater than the control (Fig. 9c); in leaves, compared to control, PSBA expression increased for all concentrations of $\mathrm{Cu}$ (Fig. 9d)
Fig. 3 TEM micrographs of roots cross sections of young $T$. cacao plants exposed to different concentrations of $\mathrm{Cu}$ in nutrient solution for $96 \mathrm{~h} .0 .005(\mathbf{a}, \mathbf{g}), 2$ $(\mathbf{b}, \mathbf{h}), 4(\mathbf{c}, \mathbf{i}), 8(\mathbf{d}, \mathbf{j}), 16(\mathbf{e}, \mathbf{k})$ and $32 \mathrm{mg} \mathrm{Cu} \mathrm{L}^{-1}$ (f, l). Arrows in $\mathbf{d}-\mathbf{f}$ indicate shrinkage of the plasma membrane and tonoplast. Arrows in $\mathbf{g - i}$ showed intact membrane. Arrows in $\mathbf{j}-\mathbf{I}$ indicate membrane rupture. $\mathrm{cw}$ cell wall, $m$ mitochondria. Bars $0.5 \mu \mathrm{m}(\mathbf{g}), 1 \mu \mathrm{m}(\mathbf{h}, \mathbf{i}, \mathbf{k}$, and $\mathbf{l})$, $2 \mu \mathrm{m}(\mathbf{b}-\mathbf{e}$ and $\mathbf{j}), 5 \mu \mathrm{m}$ (a, c, and $\mathbf{f}$ )
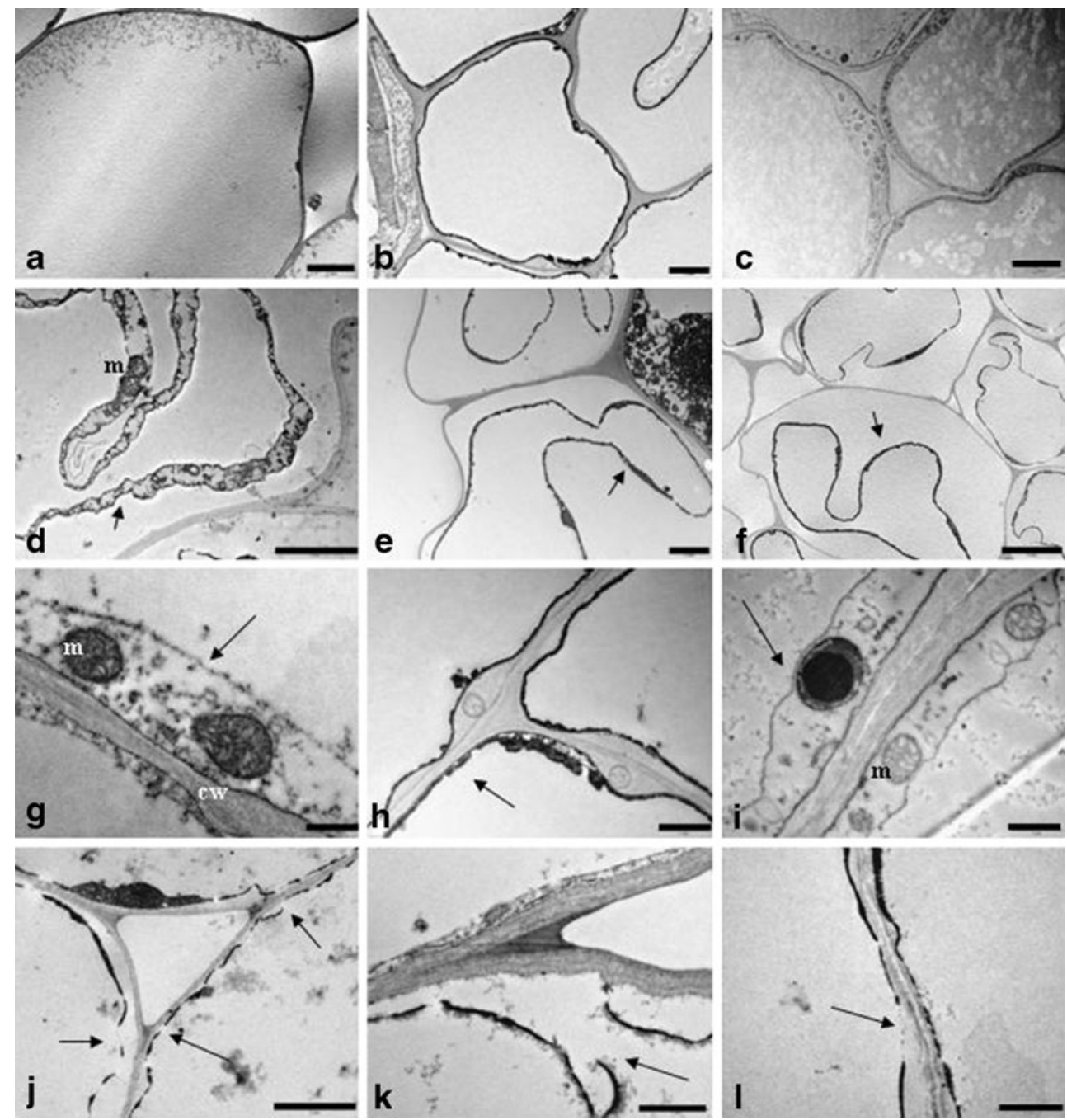
Fig. 4 TEM micrographs of cross sections of leaf mesophyll of young T. cacao plants exposed to different concentrations of $\mathrm{Cu}$ in nutrient solution for $96 \mathrm{~h}$. 0.005 (a), 2 (b), 4 (c), 8 (d), 16 (e) and $32 \mathrm{mg} \mathrm{Cu} \mathrm{L}^{-1}$ (f). Arrows in $\mathbf{a}, \mathbf{b}$, and $\mathbf{c}$ indicate the thylakoid membranes. Arrows in $\mathbf{d}, \mathbf{e}$, and $\mathbf{f}$ show rupture of the double membrane surrounding the chloroplast, thylakoids swollen, and increase in intrathylakoidal spaces. $c w$ cell wall, $m$ mitochondria, $n$ nucleus, $p g$ plastoglobuli, $s g$ starch grains. Bars $1 \mu \mathrm{m}(\mathbf{a}, \mathbf{b}$, and $\mathbf{f})$, $2 \mu \mathrm{m}(\mathbf{c}, \mathbf{d}$, and $\mathbf{e})$
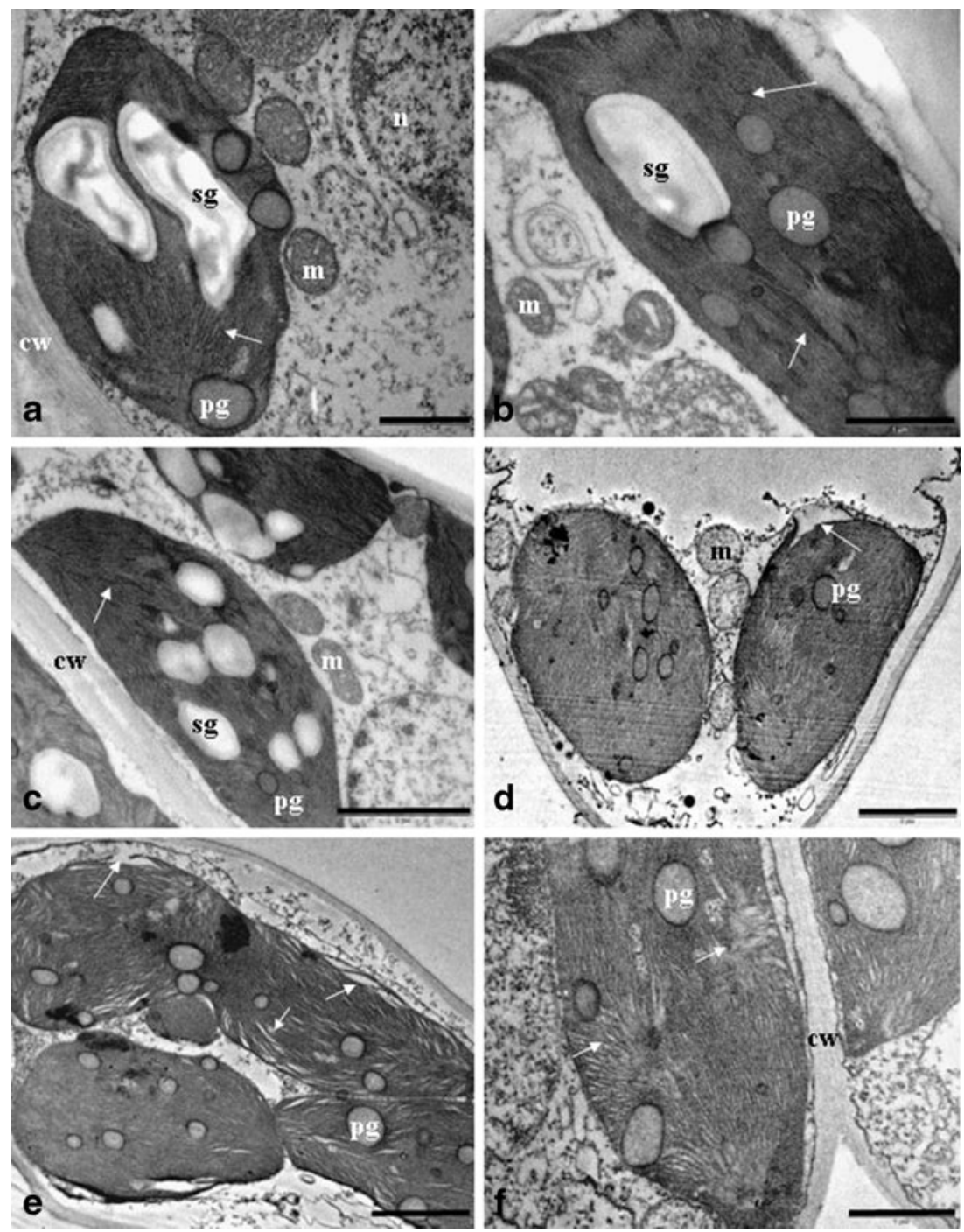

whereas expression of $P S B O$ increased only for the low concentrations of 2 and $4 \mathrm{mg} \mathrm{Cu} \mathrm{L}^{-1}$ (Fig. 9e). Furthermore, transcriptions of MT2b and SODCyt genes in the leaves at $12 \mathrm{~h} \mathrm{AAT} \mathrm{for}$ the $2 \mathrm{mg} \mathrm{Cu} \mathrm{L}^{-1}$ dose were repressed when compared to control, whereas at the 4 and $8 \mathrm{mg} \mathrm{Cu} \mathrm{L}^{-1}$ concentrations, genes transcription increased (Fig. 9f, g). Expression of $M T 2 b$ and SODCyt at $96 \mathrm{~h} \mathrm{AAT}$, at all concentrations of $\mathrm{Cu}$, was greater than at $12 \mathrm{~h}$ AAT, and increased with increasing concentration of $\mathrm{Cu}$ in the nutrient solution (Fig. 9f, g). The SODChl gene transcripts increased at $12 \mathrm{~h}$ AAT for the $8 \mathrm{mg} \mathrm{Cu} \mathrm{L}^{-1}$ dose, and at $96 \mathrm{~h}$ AAT for the concentration $2 \mathrm{mg} \mathrm{Cu} \mathrm{L}^{-1}$, whereas its expression levels were suppressed at $96 \mathrm{~h} \mathrm{AAT}$ for the $8 \mathrm{mg} \mathrm{Cu}$ $\mathrm{L}^{-1}$ treatment (Fig. 9h).

\section{Discussion}

Concerns about the accumulation of $\mathrm{Cu}$ in $T$. cacao beans up to levels potentially inappropriate for human consumption have been recently raised in southeastern Bahia, the most important cacao-producing region in Brazil. These concerns resulted from studies showing that a direct proportion exists between increased $\mathrm{Cu}$ levels in cacao-growing soils and the number of years of application of $\mathrm{Cu}$-based fungicides (Veloso and Santana 2000). Hence, it became necessary to investigate if such increases in soil $\mathrm{Cu}$ levels could lead to corresponding increases in the levels of $\mathrm{Cu}$ in cacao tissues, or to an altered physiology that could affect cacao production. Due to a much more precise control of $\mathrm{Cu}$ levels in nutrient solution, cacao seedlings were used as experimental models in the present work, aiming to quantify potential $\mathrm{Cu}$ increases in tissues, as well as to assess their effects in physiology, cellular ultrastructure, mineral composition and stress-response gene expression.

The inhibitory effects of excessive $\mathrm{Cu}$ on photosynthetic processes have been investigated in different plant species (Maksymiec 1997; Pätsikkä et al. 2002; Shi-Sheng 2007; Cambrollé et al. 2011). Results from studies in Triticum aestivum 


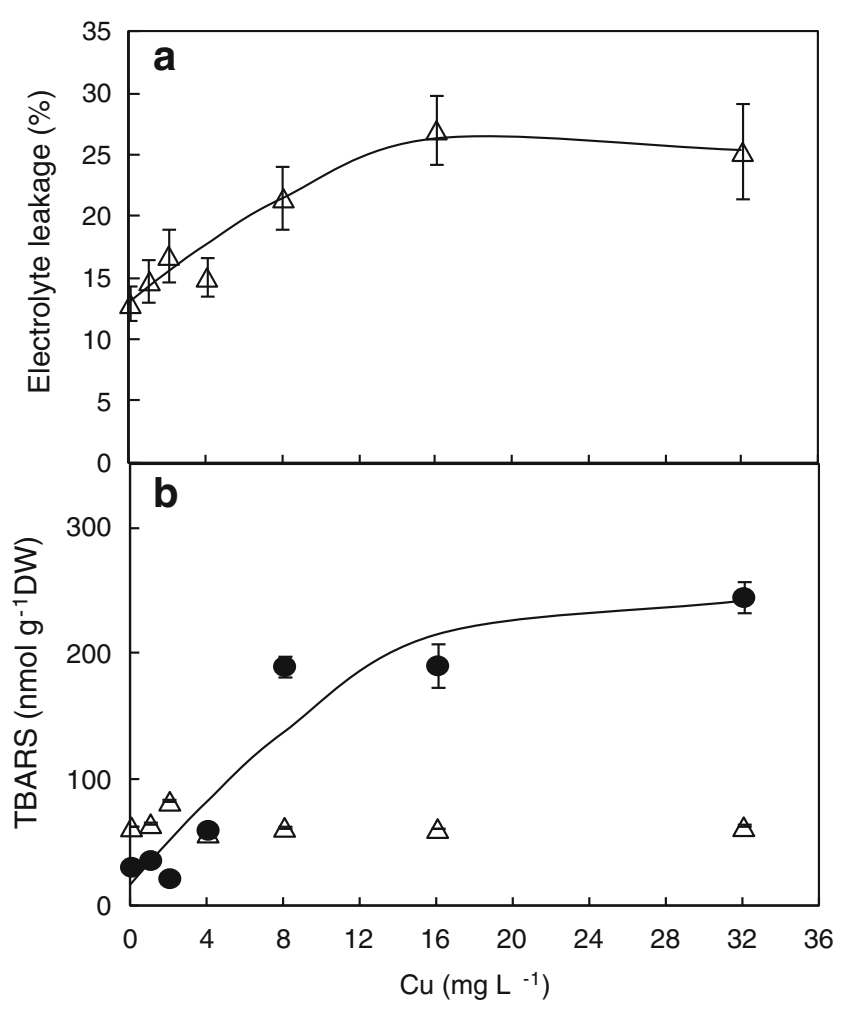

Fig. 5 Electrolyte leakage and lipid peroxidation in leaves and roots of young T. cacao plants exposed to different concentrations of $\mathrm{Cu}$ in nutrient solution for $96 \mathrm{~h}, n=4, \pm$ SE. a Percentage of electrolyte leakage in leaves, the equation of the regression curve was $\hat{y}=12.98+1.28 x-0.02 x^{2}\left(r^{2}=0.94\right)$. b Concentration of thiobarbituric acid-reactive substances (TBARS) in roots (filled circle) and leaves (open upright triangle), the equations of regression curves were: $\widehat{y}=15.88+17.84 x-0.33 x^{2}\left(r^{2}=0.90\right)$ for roots; $\widehat{y}=65.26$ for leaves

(Moustakas et al. 1997), Hordeum vulgare (Vassilev et al. 2002), and G. flavum (Cambrollé et al. 2011) have shown to be similar to those of $T$. cacao, with observed decreases in leaf gas

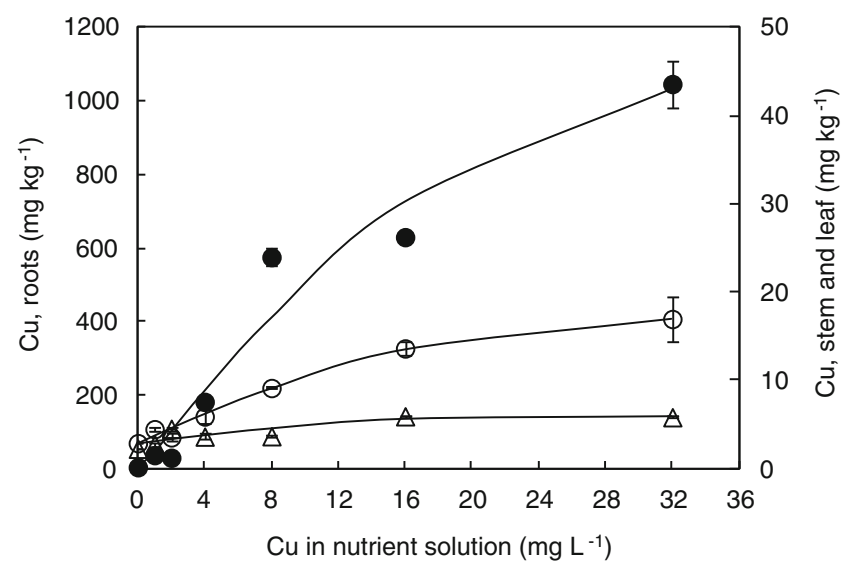

Fig. 6 Variation of $\mathrm{Cu}$ concentration in roots (filled circle), stems (open circle), and leaves (open upright triangle) of young T. cacao plants exposed to increasing concentrations of $\mathrm{Cu}$ in nutrient solution for $96 \mathrm{~h}, n=3, \pm \mathrm{SE}$. The equations of regression curves were: $\widehat{y}=1303.212\left(1-0.95^{x}\right)\left(r^{2}=\right.$ $0.95)$ for roots; $\widehat{y}=2.78+0.89 x-0.014 x^{2}\left(r^{2}=0.99\right)$ for stems; $\widehat{y}=$ $2.77+0.25 x-0.004 x^{2}\left(r^{2}=0.77\right)$ for leaves

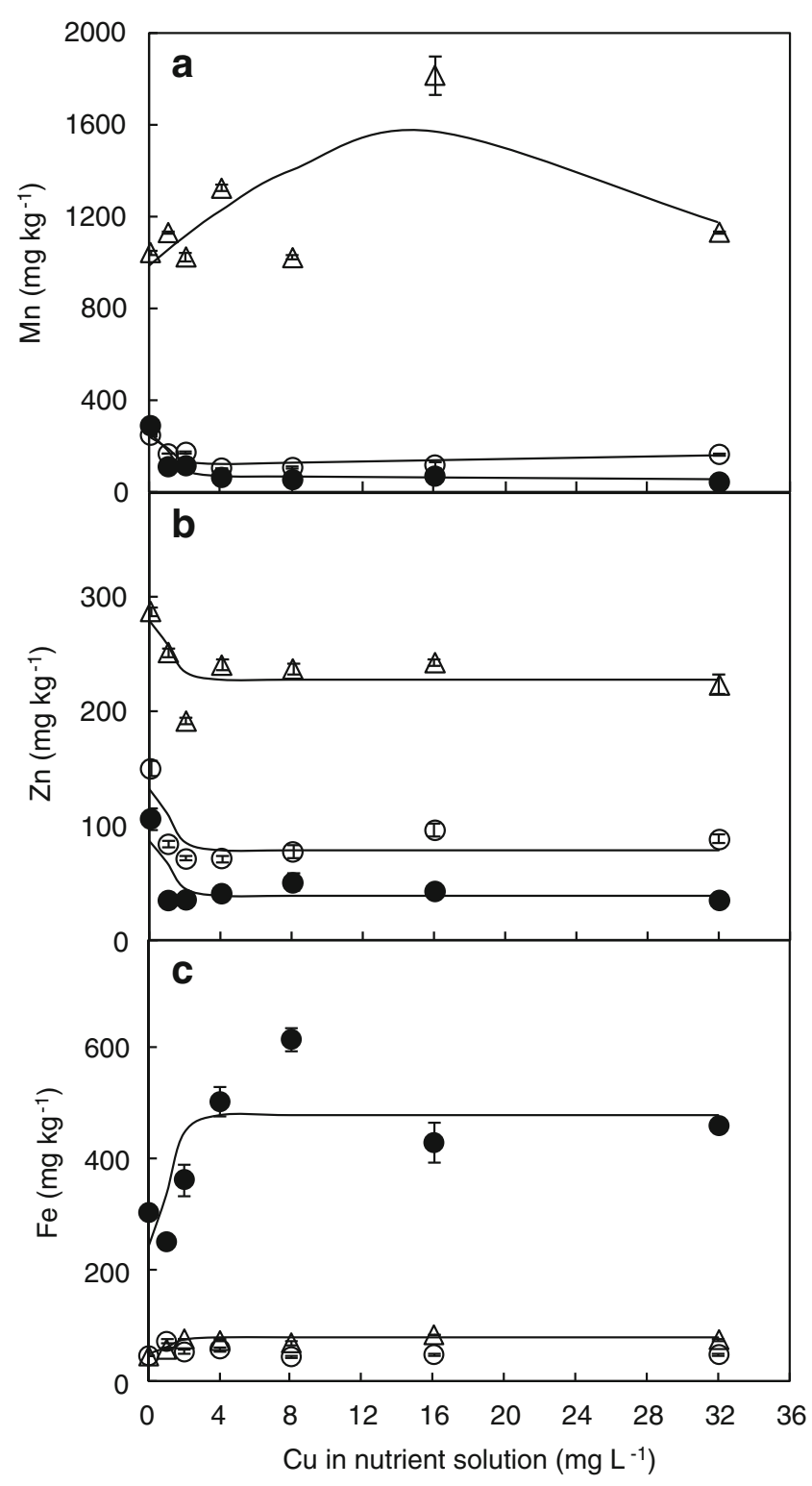

Fig. 7 Changes in the concentrations of $\mathrm{Mn}, \mathrm{Fe}$, and $\mathrm{Zn}$ in roots (filled circle), stems (open circle), and leaves (open upright triangle) of young $T$. cacao plants exposed to increasing concentrations of $\mathrm{Cu}$ in nutrient solution for $96 \mathrm{~h}, n=3, \pm \mathrm{SE}$. The equations of regression curves for Mn were $\widehat{y}=64.69-0.49 x+188.05\left(\exp \left(-\left(x^{2}\right) / 2\right)\right)\left(r^{2}=0.84\right)$ for roots; $\hat{y}=$ $109.92-1.41 x+130.23\left(\exp \left(-\left(x^{2}\right) / 2\right)\right)\left(r^{2}=0.79\right)$ for stems and $\hat{y}=980.49+67.78 x-1.93 x^{2}\left(r^{2}=0.52\right)$ for leaves; for $\mathrm{Zn}$ were $\widehat{y}=38.36+48.37\left(\exp \left(-\left(x^{2}\right) / 2\right)\right)\left(r^{2}=0.56\right)$ for roots; $\hat{y}=78.72+$ $54.08\left(\exp \left(-\left(x^{2}\right) / 2\right)\right)\left(r^{2}=0.62\right)$ for stems and $\hat{y}=227.10+51.71$ $\left(\exp \left(-\left(x^{2}\right) / 2\right)\right)\left(r^{2}=0.51\right)$ for leaves; for Fe were $\widehat{y}=476.58-232.5$ $3\left(\exp \left(-\left(x^{2}\right) / 2\right)\right)\left(r^{2}=0.56\right)$ for roots; $\hat{y}=55.73$ for stems and $\widehat{y}=79.03-30.07\left(\exp \left(-\left(x^{2}\right) / 2\right)\right)\left(r^{2}=0.86\right)$ for leaves

exchange parameters after treatment with excess of $\mathrm{Cu}$. In our study, seedlings exposure to $\mathrm{Cu}$ concentrations above $8 \mathrm{mg} \mathrm{Cu}$ $\mathrm{L}^{-1}$ showed to be highly toxic to $T$. cacao, as indicated by the sharp net photosynthetic decline after only $24 \mathrm{~h}$ of treatment application. This decrease was interpreted to be directly related to the observed decrease in gs, which indicates that the stomata have closed, with a consequent increase in diffusive resistance to 


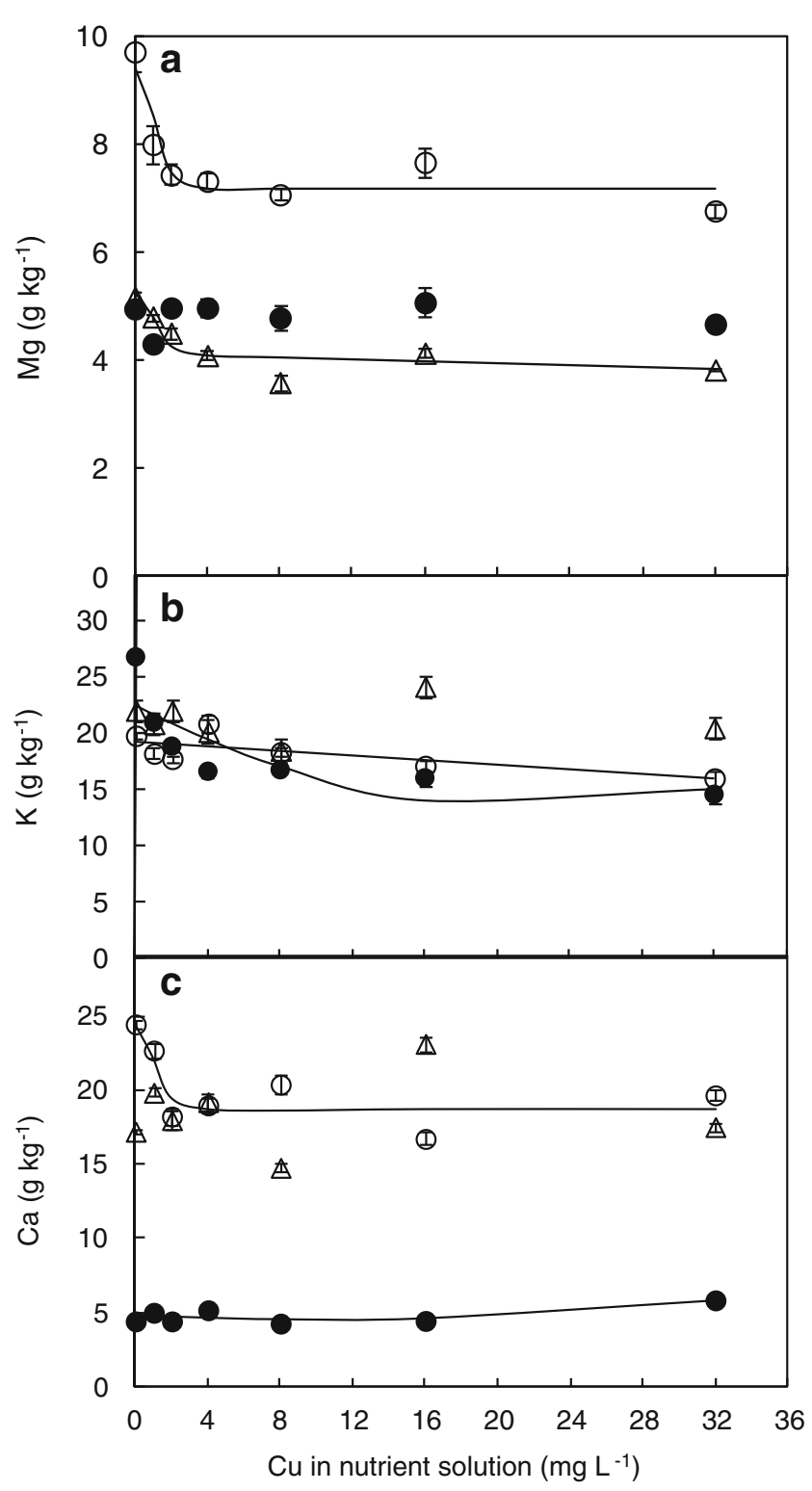

Fig. 8 Variation of the levels of $\mathrm{Mg}, \mathrm{K}$, and $\mathrm{Ca}$ in roots (filled circle), stems (open circle) and leaves (open upright triangle) of young T. cacao plants exposed to increasing concentrations of $\mathrm{Cu}$ in nutrient solution for $96 \mathrm{~h}, n=3, \pm \mathrm{SE}$. The equations of regression curves for $\mathrm{Mg}$ were $\widehat{y}=4.73$ for roots; $\hat{y}=78.72+54.08\left(\exp \left(-\left(x^{2}\right) / 2\right)\right)\left(r^{2}=0.62\right)$ for stems and $\hat{y}=4.60$ for leaves; for $\mathrm{K}$ were $\hat{y}=22.46-0.82 x+$ $0.018 x^{2}\left(r^{2}=0.65\right)$ for roots; $\hat{y}=19.23-0.104 x\left(r^{2}=0.54\right)$ for stems and $\hat{y}=21.15$ for leaves; for Ca were $\hat{y}=4.76-0.063 x+$ $0.003 x^{2}\left(r^{2}=0.65\right)$ for roots; $\hat{y}=18.76+5.84\left(\exp \left(-\left(x^{2}\right) / 2\right)\right)$ $\left(r^{2}=0.77\right)$ for stems and $\widehat{y}=18.35$ for leaves

$\mathrm{CO}_{2}$ and reduction in water loss by transpiration, confirmed by the observed reduction in $E$ (Figs. 1 and 2). It was found that $T$. cacao plants tolerated exposures up to $4 \mathrm{mg} \mathrm{Cu} \mathrm{L}^{-1}$, despite the observed decrease in $P_{\mathrm{N}}$ at $96 \mathrm{~h}$ AAT, which can be considered an indirect effect of the decreases in gs and $E$ observed as early as $24 \mathrm{~h}$ AAT. Exposure to lower $\mathrm{Cu}$ concentrations (1 and $2 \mathrm{mg} \mathrm{L}^{-1}$ ) did not affect the cacao physiology negatively, or alternatively, it might have had a beneficial effect to the plants, possibly as a micronutrient within the favorable limits. At least part of the $\mathrm{Cu}$ effects in photosynthesis derives from the fact that this metal is a component of plastocyanin, and as such, has a direct participation in the electron transport between PS II and PS I in the photochemical phase of photosynthesis. In addition, $\mathrm{Cu}$ excess can cause changes in proteins and lipids of thylakoid membranes, leading to a susceptibility of PS II to photoinhibition in vivo and to impairment of the electron transport between the two photosystems (Maksymiec 1997; Pätsikkä et al. 1998; 2002).

The reduction in $E$ and gs values as a result of stomatal closure promoted by higher $\mathrm{Cu}$ concentrations has likely favored the decline in $P_{\mathrm{N}} / \mathrm{gs}$ and $W U E$ at $72 \mathrm{~h}$ AAT (Fig. 1d, e). This was possibly due to an inefficient absorption of water by the roots and a poor translocation of water and mineral nutrients to the shoots, as suggested by the ultrastructural changes in cells of the root tip cortex. Concentrations equal and above $8 \mathrm{mg} \mathrm{Cu} \mathrm{L}{ }^{-1}$ considerably affected root cells by promoting plasmolysis, likely due to osmotic effects and disruption of the plasma membrane (Fig. 3). Panou-Filotheou and Bosabalidis (2004) have also observed plasmolysis, disintegration of cell membranes and non-recognition of any organelles in root cells of Origanum vulgare plants exposed to $\mathrm{Cu}$ stress. In leaves of T. cacao seedlings exposed to higher levels of $\mathrm{Cu}$, the damage imposed to the thylakoid membranes and chloroplast's double membrane certainly contributed to the observed changes in leaf gas exchange. Storage of starch grains in chloroplasts was not observed, likely due to a sharp decline in carbon assimilation and to mobilization of all assimilated compounds from the current photosynthesis to other metabolic drains. Symptoms of starch grains absence and swelling of chloroplasts double membrane have also been identified in leaves of $O$. vulgare after $\mathrm{Cu}$ treatment (Panou-Filotheou et al. 2001). In Populus tremula plants grown in soil containing a mixture of heavy metals including $\mathrm{Cu}$, breakages in thylakoid membranes and chloroplast envelope were observed, with extrusion of waste material to the cytoplasm (Hermle et al. 2007). Swelling of thylakoid and increased interthylakoidal spaces were also featured in chloroplasts of T. aestivum under Zn-deficiency stress (Peck and McDonald 2010).

The loss of membrane integrity in root and leaf cells of $T$. cacao was evaluated by the levels of lipid peroxidation. TBARS concentrations increased up to $15 \times$ in roots for the highest $\mathrm{Cu}$ dose, suggesting that, above $4 \mathrm{mg} \mathrm{Cu} \mathrm{L}^{-1}$, changes in cell membranes were due to lipids degradation. On the other hand, in leaf mesophyll cells, the damage to chloroplasts (Fig. 4) and the increase in electrolyte leakage (Fig. 5) appear to be related to possible effects of $\mathrm{Cu}$ on membrane proteins, because there was no significant difference $(p<0.05)$ between the concentration of TBARS in control and in $\mathrm{Cu}$ treatments. However, as we discuss below, $\mathrm{Cu}$ was mostly retained in the root system, thereby suggesting that the ultrastructural effects on roots and leaf cells are of a different nature. Excessive 
Fig. 9 Amount of transcripts in the roots $(\mathbf{a}-\mathbf{c})$ and leaves $(\mathbf{d}-\mathbf{h})$ of young T. cacao plants exposed to increasing concentrations of $\mathrm{Cu}$ in nutrient solution for 12 and $96 \mathrm{~h}(n=3, \pm \mathrm{SE})$. The mRNA levels were quantified by quantitative real-time PCR. The mRNA levels were normalized with respect to tubulin, and are expressed relative to those of control plants that were given a value of 1. Uppercase letters compare averages between treatments $12 \mathrm{~h} \mathrm{AAT}$ and lowercase letters compare averages between treatments $96 \mathrm{~h}$ AAT. Means followed by the same letter are not significantly different at $p<0.05$, according to Tukey's test

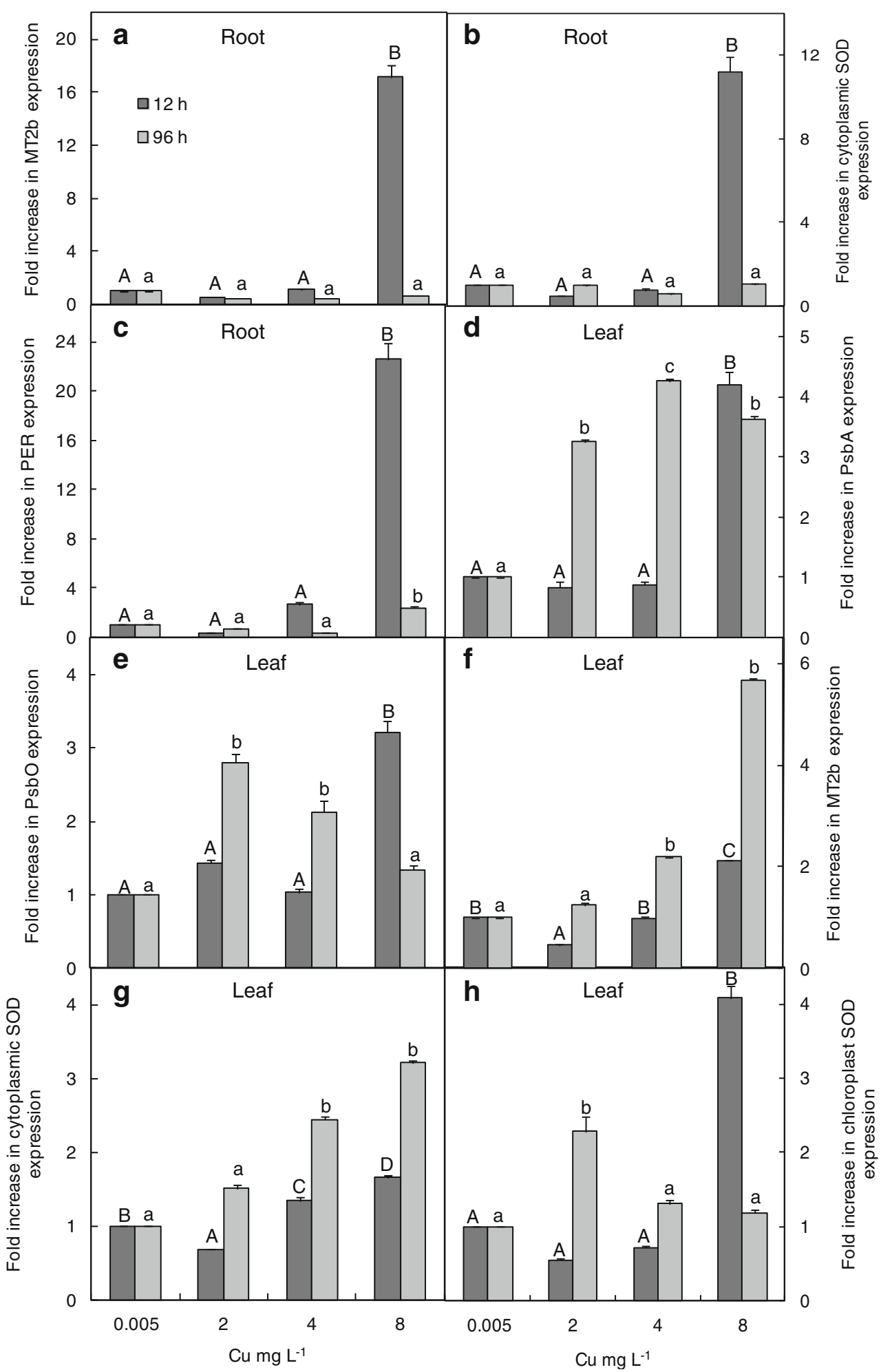

amounts of $\mathrm{Cu}$ showed to induce oxidative stress responses, with the formation of ROS that cause lipid peroxidation of cell membranes and increases in TBARS levels (mainly MDA) in plant cells (Pätsikkä et al. 2002; Janas et al. 2010). Moreover, $\mathrm{Cu}$ can also damage the membranes by reacting with sulfhydryl groups, which lead to proteins denaturation (Panou-Filotheou and Bosabalidis 2004).

The observed low mobility of $\mathrm{Cu}$ within the T. cacao plant, as suggested by its major accumulation in the root system (Fig. 6), confirms similar results in other studies in 
various plant species (Pätsikkä et al. 2002; Panou-Filotheou and Bosabalidis 2004; Shin-Sheng 2007; Bouazizi et al. 2010; Cambrollé et al. 2011). It has been suggested that the preferential accumulation of $\mathrm{Cu}$ in roots is the result of a tolerance mechanism in plants to cope with the stress caused by this metallic element at high concentrations (Bouazizi et al. 2010). When such mechanisms of $\mathrm{Cu}$ tolerance in the root zone become overloaded, $\mathrm{Cu}^{+2}$ is then translocated to shoots through xylem and phloem. When it reaches the leaves, a small proportion of $\mathrm{Cu}$ accumulates in the chloroplasts, which is likely responsible for the ultrastructural damages observed (Figs. 3 and 4). Taken together, these results suggest that the transport of this metal is a highly regulated process, even in plants exposed to $\mathrm{Cu}$ excess (Pätsikkä et al. 2002). Patterns of stress-response gene expression obtained (and discussed further below) come into support of this view. A crop-cultivating soil is a physicochemically and biologically dynamic entity, such that distribution and availability of any element to plants tend not to occur in a uniform and homogenous manner; soil patches of different sizes, composition and locations compose a mosaic that will display distinct forms and concentrations of the various soil elements available to plants. Hence, in a cacao production field, we can reasonably speculate that the protection against excess of $\mathrm{Cu}$ in adult plants operates at the level of morphological and gene expression changes in the root system, likely to avoid absorption and/or prevent this element to translocate to more sensitive tissues/cells of the plant.

Despite its low mobility, and accumulation mainly in the root system, $\mathrm{Cu}$ affects the transport of other essential mineral nutrients for plant metabolism (Shaul 2002; Xiong et al. 2002), as shown in this study. The uptake of $\mathrm{Mn}$ and $\mathrm{Zn}$ by roots of $T$. cacao seedlings was significantly affected with increasing $\mathrm{Cu}$ in the nutrient solution. However, the levels of these elements in leaves were practically unchanged, possibly due to the fact that they are critical for photosynthetic processes. Mn is an essential cofactor in the water oxidation pathway of PS II (Dučić and Polle 2005). Zn occurs in high concentrations in biological systems when compared with other micronutrients. $\mathrm{Zn}$ helps maintaining the structural integrity and controlling the permeability of cell membranes, it is critically important for cells protection from ROS-induced damages (Cakmak 2000). Thus, the decrease of $\mathrm{Zn}$ in T. cacao roots may have contributed to the disruption and lipid peroxidation of cell membranes, as observed by ultrastructural analysis (Figs. 3 and 4) and TBARS quantification (Fig. 5). Moreover, in many monocots and eudicots, $\mathrm{Zn}$ deficiency causes accumulation of $\mathrm{Fe}$ in roots and shoots, which is associated with increased lipid peroxidation and damage to the chlorophyll molecules in plants under stressing conditions (Cakmak 2000). The $\mathrm{Cu}$-associated increase in Fe content that occurred in roots and leaves of the studied seedlings was likely coupled to the decline in $\mathrm{Zn}$ and may have also influenced the damage observed in cell membranes and in photosynthetic rates.
The Mg element in plants has the ability to interact with nucleophilic ligands (Shaul 2002). It is the central atom of the chlorophyll molecule and is an important element for ribosomal subunits aggregation during protein biosynthesis. In chloroplasts, $\mathrm{Mg}^{2+}$ is required to activate Rubisco, thereby resulting in $\mathrm{CO}_{2}$ fixation (Shaul 2002). When plant species are submitted to excessive amounts of $\mathrm{Cu}, \mathrm{Mg}$ can be chemically replaced by this element in the chlorophyll molecule, leading to a decline in photosynthesis (Kupper et al. 1998). Hence, the decrease in $\mathrm{Mg}$ concentration in shoots of T. cacao and its replacement by $\mathrm{Cu}$ in chlorophyll may have contributed to the decline in assimilation rates of $\mathrm{CO}_{2}$ in this species. With regards to $\mathrm{K}$, a decline in its levels often indicates efflux of this element across a plasma membrane, which was likely damaged by the lipid peroxidation promoted by $\mathrm{Cu}$ excess, resulting in loss of membrane selectivity and increase in its permeability (Murphy et al. 1999; Janas et al. 2010). Toxic levels of $\mathrm{Cu}$ can also inhibit membrane ATPases and promote increased cytoplasmic concentrations of $\mathrm{Ca}$, due to blockage in ATP-dependent pumping of $\mathrm{Ca}$ to the outside of the cell. The $\mathrm{Cu}$-induced increase of cytoplasmic $\mathrm{Ca}$ levels triggers various catabolic processes by activation of phospholipases, which result in the formation of free radicals (Maksymiec 1997).

Transcriptional analysis of gene expression by qPCR suggests that the antioxidant defense systems and abiotic stress tolerance in seedlings were sharply stimulated by $\mathrm{Cu}$ excess in nutrient solution. Up-regulation of metallothioneins in plants has been constantly related to $\mathrm{Cu}$ homeostasis by detoxification and protection against oxidative stress (Cobbett and Goldsbrough 2002; Cozza et al. 2012). The increased expression of $M T 2 b$ only $12 \mathrm{~h}$ AAT implies that the protection strategy adopted by $T$. cacao is to tolerate and accumulate high levels of $\mathrm{Cu}$ in the root system, in order to ensure the maintenance of metabolism in leaves. Studies with Silene vulgaris tolerant to $\mathrm{Cu}$ have shown higher levels of mRNA transcripts for $M T 2 b$ (van Hoof et al. 2001). On their turn, the increased expression of SODCyt and PER-1 in roots, and SODChl and SODCyt in leaves of T. cacao suggest the existence of a defense mechanism against oxidative stress promoted by $\mathrm{Cu}$, by the expression of genes encoding antioxidant enzymes (Lee et al. 2007). The SOD enzymes constitute the first line of cellular defense against ROS (Alscher et al. 2002), whereas the class III peroxidases are involved in the formation of lignin and suberin, as well as in maintaining adequate levels of ROS (Almagro et al. 2009).

The gene $p s b O$ encodes a protein that is extrinsic to the oxygen evolution center located in PS II, being considered as the main protein responsible for water photolysis (De Las Rivas et al. 2004). Mutants of Arabidopsis thaliana that lack the $p s b O$ gene have shown a decreased activity of the PS II (Murakami et al. 2002). In turn, $p s b A$ is located in the chloroplast genome and encodes a protein, PsbA or D1 that is intrinsic to the PS II (Nelson and Yocum 2006). Since 
stresses caused by heavy metals promote reduction of $p s b A$ gene transcripts, and so, interfere with the operation of PS II (Geiken et al. 1998; Allakhverdiev et al. 2002), the decreases in T. cacao leaf gas exchange is likely related to damage to PS II as described for other plant species subjected to stress by $\mathrm{Cu}$ (Maksymiec 1997; Pätsikkä et al. 2002). The exposure of $T$. cacao seedlings to $8 \mathrm{mg} \mathrm{Cu} \mathrm{L}^{-1}$ stimulated an increase in $P S B A$ and $P S B O$ transcripts at $12 \mathrm{~h}$ AAT, likely to prevent damage to PS II. However, at $96 \mathrm{~h}$ AAT, their expression was lower than in the 2 and $4 \mathrm{mg} \mathrm{Cu} \mathrm{L}^{-1}$ doses (Fig. 9), suggesting that inhibition in their transcription has likely started from this level on. This would be in agreement with the fact that there was no recovery of the leaf gas exchange after treatments with higher $\mathrm{Cu}$ doses, as previously discussed (Fig. 1). The levels of transcripts of $P S B A$ and $P S B O$ at $96 \mathrm{~h}$ AAT increased for the 2 and $4 \mathrm{mg} \mathrm{Cu} \mathrm{L}^{-1}$, suggesting that $T$. cacao tolerates well up to these $\mathrm{Cu}$ concentrations.

Despite that exposure to $\mathrm{Cu}$ was only during a very short period of time, not addressing effects of a long-term stress, or acclimation/adaptation types of response, all the damages identified at the cellular level can be regarded as irreversible to those cells and able to affect downstream processes and metabolisms of the plant, as long as the Cu stress is maintained (Lichtentaler 1996). From the present studies with seedlings, we conclude that the $T$. cacao plants are likely capable of tolerating $\mathrm{Cu}$ concentrations from 4 to $8 \mathrm{mg} \mathrm{Cu} \mathrm{L}^{-1}$ at their root system. $\mathrm{Cu}$ doses above these levels (at least in conditions that surround the entire root system in a homogeneous and constant manner, as provided by nutrient solutions) appear to be very toxic, remarkably interfering with the overall metabolism of this species. As a tolerance strategy, $\mathrm{Cu}$ was mainly accumulated in roots and remained mostly restricted to this organ, indicating a low mobility within the plant. In this sense, this plant species appears to be a rhizofilterer of this metal. In spite of the increase expression of genes involved in tolerance to stresses, such as that caused by $\mathrm{Cu}$, the excess of this metallic element in the roots caused the loss of integrity of cell membranes through lipid peroxidation, leading to an imbalanced uptake and translocation of water and mineral nutrients to shoots. These events irreversibly compromised the ultrastructure of chloroplasts and the leaf gas exchange. Taken together, all these alterations observed in T. cacao seedlings subjected to increasing levels of $\mathrm{Cu}$ suggest that plants grown in soils with high levels of copper can be negatively affected in their growth and metabolism. Our results also indicate that the major deleterious effects of high levels of $\mathrm{Cu}$ at the root system is more likely related to potential losses in cacao productivity due to the physiological and the ultrastructural changes observed, rather than to the accumulation of $\mathrm{Cu}$ in shoot tissues at toxic levels (although this effect should not be neglected). Therefore, accumulation of $\mathrm{Cu}$ in the cacao beans at toxic levels for consumption appears not to become a problem, as environmental pollution by copper will likely strike directly on cacao production resulting in the lack of beans available for consumption.

Acknowledgments We thank Mr. Alberto José dos Santos Júnior and Ms. Valéria Ferreira Fernandes of the Electron Microscopy Center-UESC for the technical assistance on EM. V. L. Souza was supported by FAPESB (Fundação de Amparo a Pesquisa do Estado da Bahia). This work was funded by a grant from USDA, within an international cooperative agreement with CEPLAC, UESC, FUNPAB, and MARS Cacau Inc.

\section{References}

Allakhverdiev SI, Nishiyama Y, Miyairi S, Yamamoto H, Inagaki N, Kanesaki Y, Murata N (2002) Salt stress inhibits the repair of photodamaged photosystem II by suppressing the transcription and translation of psbA genes in Synechocystis. Plant Physiol 130:1443-1453

Almagro L, Gómez Ros LV, Belchi-Navarro S, Bru R, Ros Barceló A, Pedreño MA (2009) Class III peroxidases in plant defence reactions. J Exp Bot 60:377-390

Almeida A-AF, Valle RR, Mielke MS, Gomes FP (2007) Tolerance and prospection of phytoremediator woody species of $\mathrm{Cd}, \mathrm{Pb}, \mathrm{Cu}$ and Cr. Braz J Plant Physiol 19:83-98

Almeida A-AF, Valle RR (2010) Cacao: Ecophysiology of Growth and Production. In: DaMatta FM (ed) Ecophysiology of tropical tree crops. Nova Science, Hauppauge, pp 37-70

Alscher RG, Erturk N, Heath LS (2002) Role of superoxide dismutases (SODs) in controlling oxidative stress in plants. J Exp Bot 53:1331-1341

Anunciação DS, Leao DJ, Jesus RM, Ferreira SLC (2011) Use of multivariate analysis techniques for evaluation of analytical data-determination of the mineral composition of cabbage (Brassica oleracea). Food Anal Methods 4:286-292

Bajji M, Kinet J-M, Lutts S (2001) The use of the electrolyte leakage method for assessing cell membrane stability as a water stress tolerance test in durum wheat. Plant Growth Regulation 0:1-10

Bouazizi H, Jouili H, Geitmann A, El Ferjani E (2010) Copper toxicity in expanding leaves of Phaseolus vulgaris L.: antioxidant enzyme response and nutrient element uptake. Ecotoxicol Environ Safety 73:1304-1308

Cakmak I, Horst WJ (1991) Effect of aluminum on lipid peroxidation, superoxide dismutase, catalase and peroxidase activities in root tips of soybean (Glycine max). Physiol Plant 83:463-468

Cakmak I (2000) Possible roles of zinc in protecting plant cells from damage by reactive oxygen species. New Phytol 146:185-205

Cambrollé J, Mateos-Naranjo E, Redondo-Gómez S, Luque T, Figueroa ME (2011) Growth, reproductive and photosynthetic responses to copper in the yellow-horned poppy, Glaucium flavum Crantz. Environ Exp Bot 71:57-64

Cobbett C, Goldsbrough P (2002) Phytochelatins and metallothioneins: roles in heavy metal detoxification and homeostasis. Annu Rev Plant Biol 53:159-182

Cozza R, Bruno L, Bitonti MB (2012) Expression pattern of a type-2 metallothionein gene in a wild population of the psammophyte Silene nicaeensis. Protoplasma. doi:10.1007/s00709-012-0425-3

De Las RJ, Balsera M, Barber J (2004) Evolution of oxygenic photosynthesis: genome-wide analysis of the OEC extrinsic proteins. Trends Plant Sci 9:18-25

Dučić T, Polle A (2005) Transport and detoxification of manganese and copper in plants. Braz J Plant Physiol 17:103-112

Fonseca SE (1990) Avaliação de resistência a Crinipellis perniciosa em novos clones de Theobroma cacao. Rev Agrotrópica 2:137-143 
Geiken B, Masojídek J, Rizzuto M, Pompili ML, Giardi MT (1998) Incorporation of $\left[{ }^{35} \mathrm{~S}\right]$ methionine in higher plants reveals that stimulation of the D1 reaction centre II protein turnover accompanies tolerance to heavy metal stress. Plant Cell Environ 21:1265-1273

Hall JL (2002) Cellular mechanisms for metal detoxification and tolerance. J Exp Bot 53:1-11

Hermle S, Vollenweider P, Günthardt-Goerg MS, Mcquattie CJ, Matyssek R (2007) Leaf responsiveness of Populus tremula and Salix viminalis to soil contaminated with heavy metals and acidic rainwater. Tree Physiol 27:1517-1531

Hoagland DR, Arnon DI (1950) The water culture method for growing plants without soil. California Agricultural Experiment Station, Berkeley, p 32

Janas KM, Zielińska-Tomaszewskaa J, Rybaczek D, Maszewskib J, Posmyk MM, Amarowiczc R, Kosińska A (2010) The impact of copper ions on growth lipid peroxidation and phenolic compound accumulation and localization in lentil (Lens culinaris Medic.) seedlings. J Plant Physiol 167:270-276

Küpper H, Küpper F, Spiller M (1998) In situ detection of heavy metal substituted chlorophylls in water plants. Photosynthesis Res 58:123-133

Kurepa J, Van Montagu M, Inzé D (1997) Expression of $s o d C p$ and $\operatorname{sodB}$ genes in Nicotiana tabacum: effects of light and copper excess. J Exp Bot 43:2007-2014

Lee S-H, Ahsan N, Lee K-W, Kim D-H, Lee D-G, Kwak S-S, Kwon SY, Kim T-H, Lee B-H (2007) Simultaneous overexpression of both $\mathrm{CuZn}$ superoxide dismutase and ascorbate peroxidase in transgenic tall fescue plants confers increased tolerance to a wide range of abiotic stresses. J Plant Physiol 164:1626-1638

Lichtenthaler HK (1996) Vegetation stress: an introduction to the stress concept in plants. J Plant Physiol 148:4-14

Livak KJ, Schmittgen TD (2001) Analysis of relative gene expression data using real-time quantitative PCR and the 2-DDC T method. Methods 25:402-408

Maksymiec W (1997) Effect of copper on cellular processes in higher plants. Photosynthetica 34:321-342

Moustakas M, Ouzounidou G, Symeonidis L, Karataglis S (1997) Field study of the effects of excess copper on wheat photosynthesis and productivity. Soil Sci Plant Nutr 43:531-539

Murakami R, Ifuku K, Takabayashi A, Shikanai T, Endo T, Sato F (2002) Characterization of an Arabidopsis thaliana mutant with impaired psbO, one of two genes encoding extrinsic 33-kDa proteins in photosystem II. FEBS Lett 523:138-142

Murphy AS, Eisinger WR, Shaff JE, Kochian LV, Taiz L (1999) Early copper-induced leakage of $\mathrm{K}^{+}$from Arabidopsis seedlings is mediated by ion channels and coupled to citrate efflux. Plant Physiol 121:1375-1382

Nelson N, Yocum CF (2006) Structure and function of photosystems I and II. Annu Rev Plant Biol 57:521-65
Panou-Filotheou H, Bosabalidis AM, Karataglis S (2001) Effects of copper toxicity on leaves of oregano (Origanum vulgare subsp. hirtum). Ann Bot 88:207-214

Panou-Filotheou H, Bosabalidis AM (2004) Root structural aspects associated with copper toxicity in oregano (Origanum vulgare subsp. hirtum). Plant Sci 166:1497-1504

Pätsikkä E, Aro E-M, Tyystjärvi E (1998) Increase in the quantum yield of photoinhibition contributes to copper toxicity in vivo. Plant Physiol 117:619-627

Pätsikkä E, Kairavuo M, Šeršen F, Aro E-M, Tyystjärvi E (2002) Excess COPPER PREDISPOSES PHOTOSYSTEM II to photoinhibition in vivo by outcompeting iron and causing decrease in leaf chlorophyll. Plant Physiol 129:1359-1367

Peck AW, McDonald GK (2010) Adequate zinc nutrition alleviates the adverse effects of heat stress in bread wheat. Plant Soil 337:355374

Pereira JL, Ram A, de Figueiredo JM, de Almeida LC (1989) Primeira ocorrência de vassoura-de-bruxa na principal região produtora de cacau no Brasil. Rev Agrotrópica 1:79-81

Reynolds ES (1963) The use of lead citrate at high $\mathrm{pH}$ as an electron opaque-stain in electron microscopy. J Cell Biol 17:208-212

SAS INSTITUTE (1997) SAS/STAT software: changes and enhancements through release 6.12. Cary: Statistical Analysis System Institute, $\mathrm{p} 1167$

Shaul O (2002) Magnesium transport and function in plants: the tip of the iceberg. BioMetals 15:309-323

Shi-Sheng KE (2007) Effects of copper on the photosynthesis and oxidative metabolism of Amaranthus tricolor seedlings. Agr Sci in China 6:1182-1192

Stell RGD, Torrie JH (1980) Principles and procedures of statistics. McGraw-Hill, New York

van Hoof NALM, Hassinen VH, Hakvoort HWJ, Ballintijn KF, Schat H, Verkleij JAC, Ernst WHO, Karenlampi SO, Tervahauta AI (2001) Enhanced copper tolerance in Silene vulgaris (Moench) Garcke populations from copper mines is associated with increased transcript levels of a $2 \mathrm{~b}$-type metallothionein gene. Plant Physiol 126:1519-1526

Vassilev A, Lidon FC, Matos MC, Ramalho JC, Yordanov I (2002) Photosynthetic performance and content of some nutrients in cadmium- and copper-treated barley plants. J Plant Nutr 25:23432360

Veloso JLM, Santana CJL (2000) Cobre residual em solos de plantações de cacau (Theobroma cacao L.). Rev Agrotrópica 12:75-80

Xiong Z-T, Li Y-H, Xu B (2002) Nutrition influence on copper accumulation by Brassica pekinensis Rupr. Ecotoxicol Environ Safety 53:200-205

Yruela I (2005) Copper in plants. Braz J Plant Physiol 17:145-156 